\title{
LEVEL II SCOUR ANALYSIS FOR BRIDGE 7 (WFAITH00030007) on TOWN HIGHWAY 3, crossing ALGERINE BROOK, WEST FAIRLEE, VERMONT
}

Open-File Report 98-405

Prepared in cooperation with

VERMONT AGENCY OF TRANSPORTATION

and

FEDERAL HIGHWAY ADMINISTRATION

U.S. Department of the Interior

U.S. Geological Survey

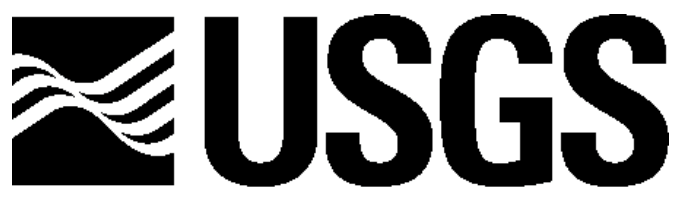

science for a changing world 


\section{LEVEL II SCOUR ANALYSIS FOR BRIDGE 7 (WFAITH00030007) on TOWN HIGHWAY 3, crossing ALGERINE BROOK, WEST FAIRLEE, VERMONT}

By MICHAEL A. IVANOFF AND ERICK M. BOEHMLER

U.S. Geological Survey Open-File Report 98-405

Prepared in cooperation with

VERMONT AGENCY OF TRANSPORTATION

and

FEDERAL HIGHWAY ADMINISTRATION

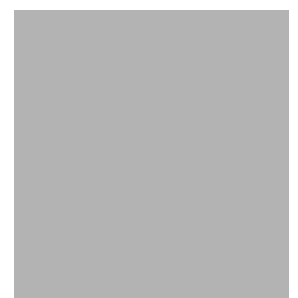




\title{
U.S. DEPARTMENT OF THE INTERIOR BRUCE BABBITT, Secretary
}

\author{
U.S. GEOLOGICAL SURVEY
}

Thomas J. Casadevall, Acting Director

For additional information write to:

District Chief

U.S. Geological Survey 361 Commerce Way

Pembroke, NH 03275-3718
Copies of this report may be purchased from:

U.S. Geological Survey

Branch of Information Services

Open-File Reports Unit

Box 25286

Denver, CO 80225-0286 


\section{CONTENTS}

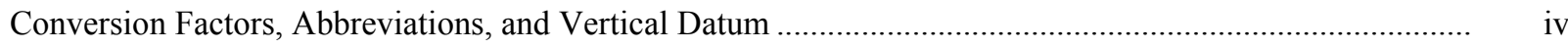

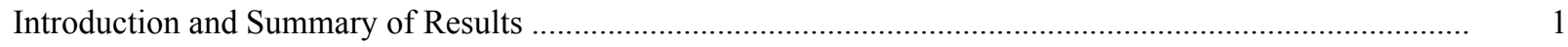

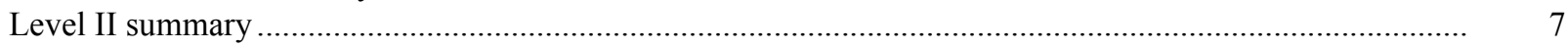

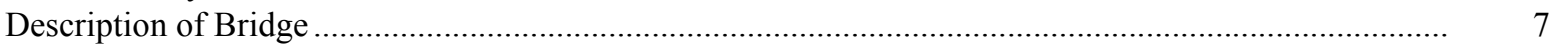



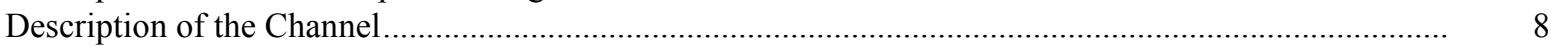

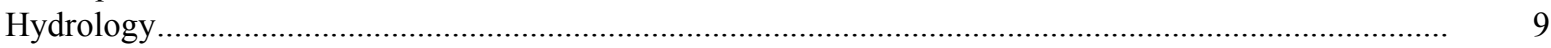

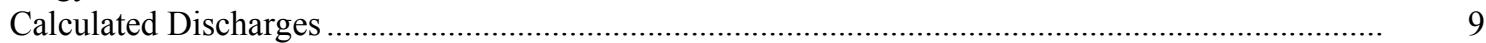





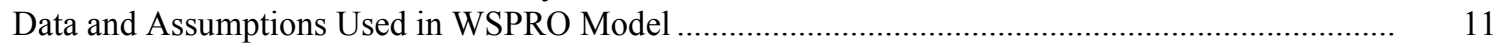





Special Conditions or Assumptions Made in Scour Analysis ................................................... 13

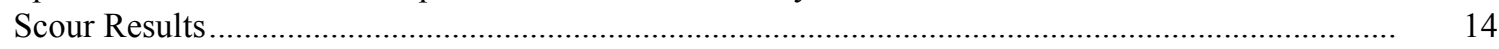



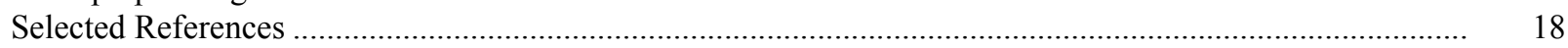

Appendices:

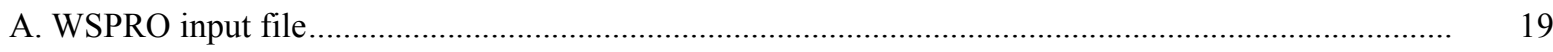

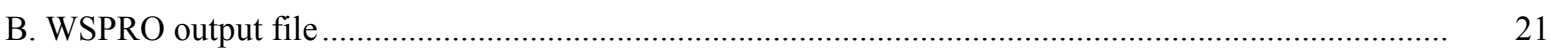



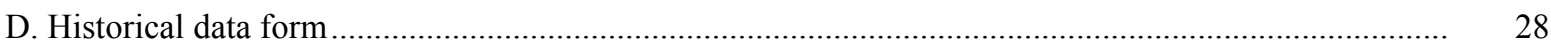



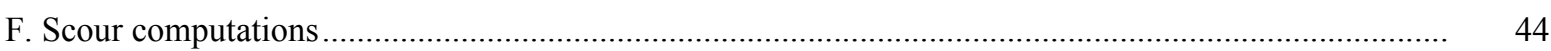

\section{FIGURES}

1. Map showing location of study area on USGS $1: 24,000$ scale map ................................................ 3

2. Map showing location of study area on Vermont Agency of Transportation town



3. Structure WFAITH00030007 viewed from upstream (September 8, 1995).................................... 5

4. Downstream channel viewed from structure WFAITH00030007 (September 8, 1995).......................... 5

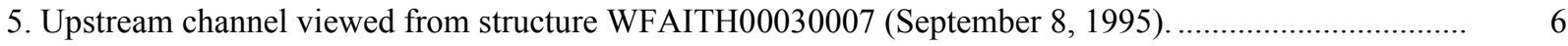

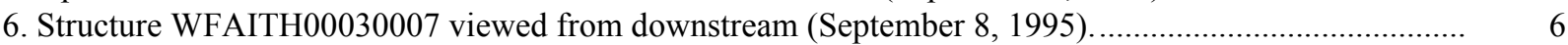

7. Water-surface profiles for the 100- and 500-year discharges at structure

WFAITH00030007 on Town Highway 3, crossing Algerine Brook,

West Fairlee, Vermont.

8. Scour elevations for the 100- and 500-year discharges at structure

WFAITH00030007 on Town Highway 3, crossing Algerine Brook,

West Fairlee, Vermont.

\section{TABLES}

1. Remaining footing/pile depth at abutments for the 100-year discharge at structure

WFAITH00030007 on Town Highway 3, crossing Algerine Brook,

West Fairlee, Vermont

2. Remaining footing/pile depth at abutments for the 500-year discharge at structure

WFAITH00030007 on Town Highway 3, crossing Algerine Brook,

West Fairlee, Vermont 


\begin{tabular}{|c|c|c|}
\hline Multiply & By & To obtain \\
\hline \multicolumn{3}{|c|}{ Length } \\
\hline inch (in.) & 25.4 & millimeter (mm) \\
\hline foot $(\mathrm{ft})$ & 0.3048 & meter $(\mathrm{m})$ \\
\hline mile (mi) & 1.609 & kilometer (km) \\
\hline \multicolumn{3}{|c|}{ Slope } \\
\hline foot per mile ( $\mathrm{ft} / \mathrm{mi})$ & 0.1894 & meter per kilometer $(\mathrm{m} / \mathrm{km})$ \\
\hline \multicolumn{3}{|c|}{ Area } \\
\hline square mile $\left(\mathrm{mi}^{2}\right)$ & 2.590 & square kilometer $\left(\mathrm{km}^{2}\right)$ \\
\hline \multicolumn{3}{|c|}{ Volume } \\
\hline cubic foot $\left(\mathrm{ft}^{3}\right)$ & $\begin{array}{l}0.02832 \\
\text { Velocity and Flow }\end{array}$ & cubic meter $\left(\mathrm{m}^{3}\right)$ \\
\hline foot per second (ft/s) & 0.3048 & meter per second $(\mathrm{m} / \mathrm{s})$ \\
\hline cubic foot per second $\left(\mathrm{ft}^{3} / \mathrm{s}\right)$ & 0.02832 & cubic meter per second $\left(\mathrm{m}^{3} / \mathrm{s}\right)$ \\
\hline $\begin{array}{l}\text { cubic foot per second per } \\
\text { square mile } \\
{\left[\left(\mathrm{ft}^{3} / \mathrm{s}\right) / \mathrm{mi}^{2}\right]}\end{array}$ & 0.01093 & $\begin{array}{l}\text { cubic meter per } \\
\text { second per square } \\
\text { kilometer }\left[\left(\mathrm{m}^{3} / \mathrm{s}\right) / \mathrm{km}^{2}\right]\end{array}$ \\
\hline
\end{tabular}

\section{OTHER ABBREVIATIONS}

\begin{tabular}{|c|c|c|c|}
\hline $\mathrm{BF}$ & bank full & LWW & left wingwall \\
\hline $\mathrm{cfs}$ & cubic feet per second & Max & maximum \\
\hline $\mathrm{D}_{50}$ & median diameter of bed material & $\mathrm{MC}$ & main channel \\
\hline DS & downstream & RAB & right abutment \\
\hline elev. & elevation & RABUT & face of right abutment \\
\hline $\mathrm{f} / \mathrm{p}$ & flood plain & $\mathrm{RB}$ & right bank \\
\hline $\mathrm{ft}^{2}$ & square feet & ROB & right overbank \\
\hline $\mathrm{ft} / \mathrm{ft}$ & feet per foot & RWW & right wingwall \\
\hline FEMA & Federal Emergency Management Agency & $\mathrm{TH}$ & town highway \\
\hline FHWA & Federal Highway Administration & UB & under bridge \\
\hline JCT & junction & US & upstream \\
\hline LAB & left abutment & USGS & United States Geological Survey \\
\hline LABUT & face of left abutment & VTAOT & Vermont Agency of Transportation \\
\hline LB & left bank & WSPRO & water-surface profile model \\
\hline LOB & left overbank & $\mathrm{yr}$ & year \\
\hline
\end{tabular}

In this report, the words "right" and "left" refer to directions that would be reported by an observer facing downstream. Sea level: In this report, "sea level" refers to the National Geodetic Vertical Datum of 1929-- a geodetic datum derived from a general adjustment of the first-order level nets of the United States and Canada, formerly called Sea Level Datum of 1929.

In the appendices, the above abbreviations may be combined. For example, USLB would represent upstream left bank. 


\title{
LEVEL II SCOUR ANALYSIS FOR BRIDGE 7 (WFAITH00030007) ON TOWN HIGHWAY 3, CROSSING ALGERINE BROOK, WEST FAIRLEE, VERMONT
}

\author{
By Michael A. Ivanoff and Erick M. Boehmler
}

\section{INTRODUCTION AND SUMMARY OF RESULTS}

This report provides the results of a detailed Level II analysis of scour potential at structure WFAITH00030007 on Town Highway 3 crossing Algerine Brook, West Fairlee, Vermont (figures 1-8). A Level II study is a basic engineering analysis of the site, including a quantitative analysis of stream stability and scour (FHWA, 1993). Results of a Level I scour investigation also are included in appendix E of this report. A Level I investigation provides a qualitative geomorphic characterization of the study site. Information on the bridge, gleaned from Vermont Agency of Transportation (VTAOT) files, was compiled prior to conducting Level I and Level II analyses and is found in appendix D.

The site is in the New England Upland section of the New England physiographic province in central Vermont. The $7.7-\mathrm{mi}^{2}$ drainage area is in a predominantly rural and forested basin. In the vicinity of the study site, the surface cover is forest.

In the study area, Algerine Brook has an incised, sinuous channel with a slope of approximately $0.02 \mathrm{ft} / \mathrm{ft}$, an average channel top width of $31 \mathrm{ft}$ and an average bank height of $3 \mathrm{ft}$. The channel bed material ranges from cobble to boulder with a median grain size $\left(\mathrm{D}_{50}\right)$ of $101 \mathrm{~mm}(0.332 \mathrm{ft})$. The geomorphic assessment at the time of the Level I and Level II site visit on September 8, 1995, indicated that the reach was stable.

The Town Highway 3 crossing of Algerine Brook is a 25-ft-long galvanized plate arch culvert with an opening span width of $25 \mathrm{ft}$ (Vermont Agency of Transportation, written communication, March 9, 1995). The opening length of the structure parallel to the bridge face is $23.4 \mathrm{ft}$. The culvert is supported by vertical, concrete abutments with "laid-up" stone wingwalls upstream. The channel is skewed approximately 30 degrees to the opening. The opening skew-to-roadway value from the VTAOT database is 30 degrees while zero degrees was computed from surveyed points.

The scour counter measures at the site include type-2 stone fill (less than 36 inches diameter) along the downstream right bank, type-3 stone fill (less than 48 inches diameter) along the upstream right bank, and "laid-up" stone walls along the left and right downstream road embankments. Additional details describing conditions at the site are included in the Level II Summary and appendices D and $\mathrm{E}$. 
Scour depths and recommended rock rip-rap sizes were computed using the general guidelines described in Hydraulic Engineering Circular 18 (Richardson and Davis, 1995) for the 100- and 500-year discharges. Total scour at a highway crossing is comprised of three components: 1) long-term streambed degradation; 2) contraction scour (due to accelerated flow caused by a reduction in flow area at a bridge) and; 3 ) local scour (caused by accelerated flow around piers and abutments). Total scour is the sum of the three components. Equations are available to compute depths for contraction and local scour and a summary of the results of these computations follows.

Contraction scour for all modelled flows ranged from 0.0 to $1.0 \mathrm{ft}$. The worst-case contraction scour occurred at the 500-year discharge. Abutment scour ranged from 6.6 to $14.9 \mathrm{ft}$. The worst-case abutment scour occurred at the 500-year discharge. Additional information on scour depths and depths to armoring are included in the section titled "Scour Results". Scoured-streambed elevations, based on the calculated scour depths, are presented in tables 1 and 2. A cross-section of the scour computed at the bridge is presented in figure 8. Scour depths were calculated assuming an infinite depth of erosive material and a homogeneous particle-size distribution.

It is generally accepted that the Froehlich equation (abutment scour) gives "excessively conservative estimates of scour depths" (Richardson and Davis, 1995, p. 46). Usually, computed scour depths are evaluated in combination with other information including (but not limited to) historical performance during flood events, the geomorphic stability assessment, existing scour protection measures, and the results of the hydraulic analyses. Therefore, scour depths adopted by VTAOT may differ from the computed values documented herein. 


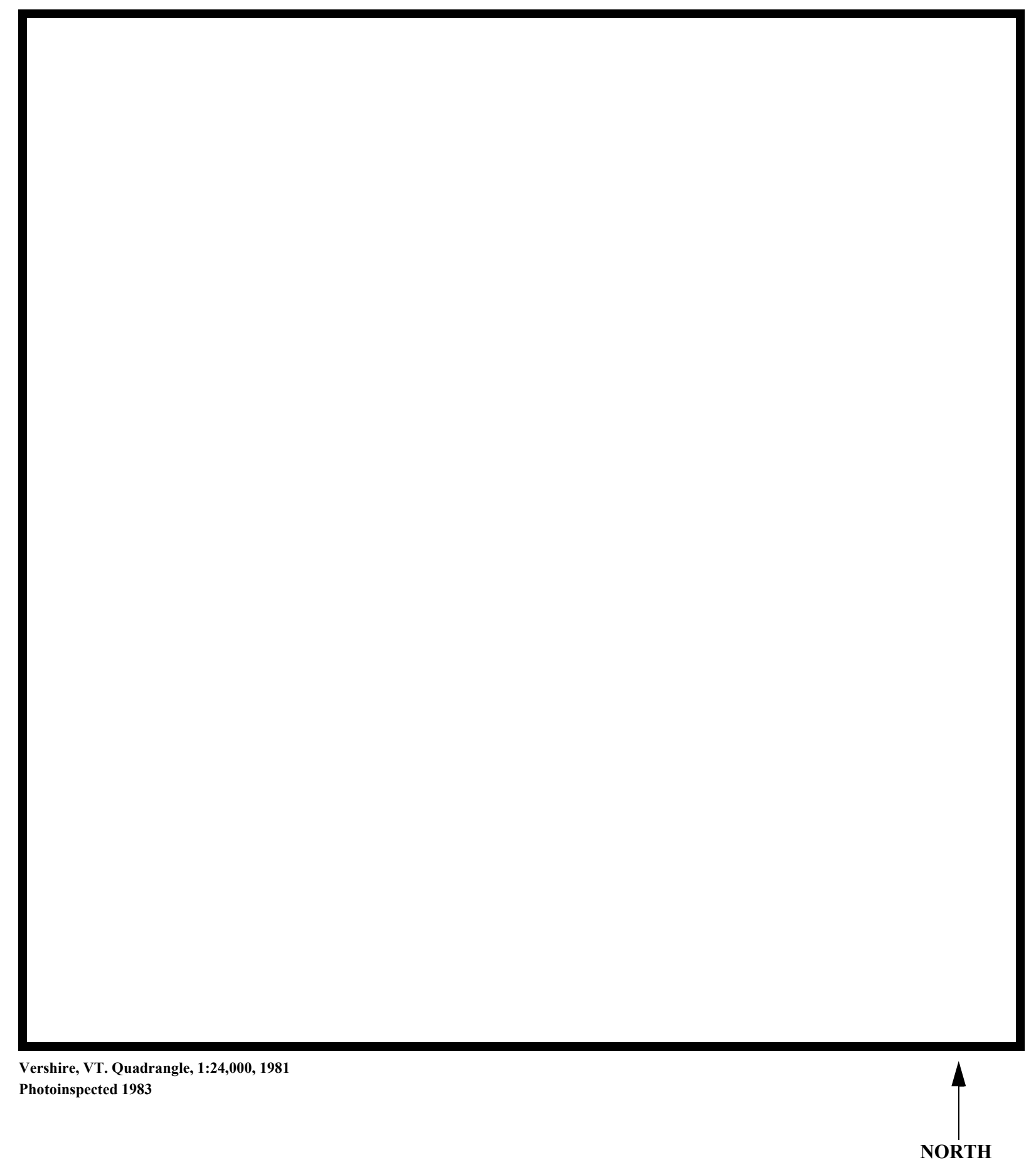

Figure 1. Location of study area on USGS 1:24,000 scale map. 
Figure 2. Location of study area on Vermont Agency of Transportation town highway map. 

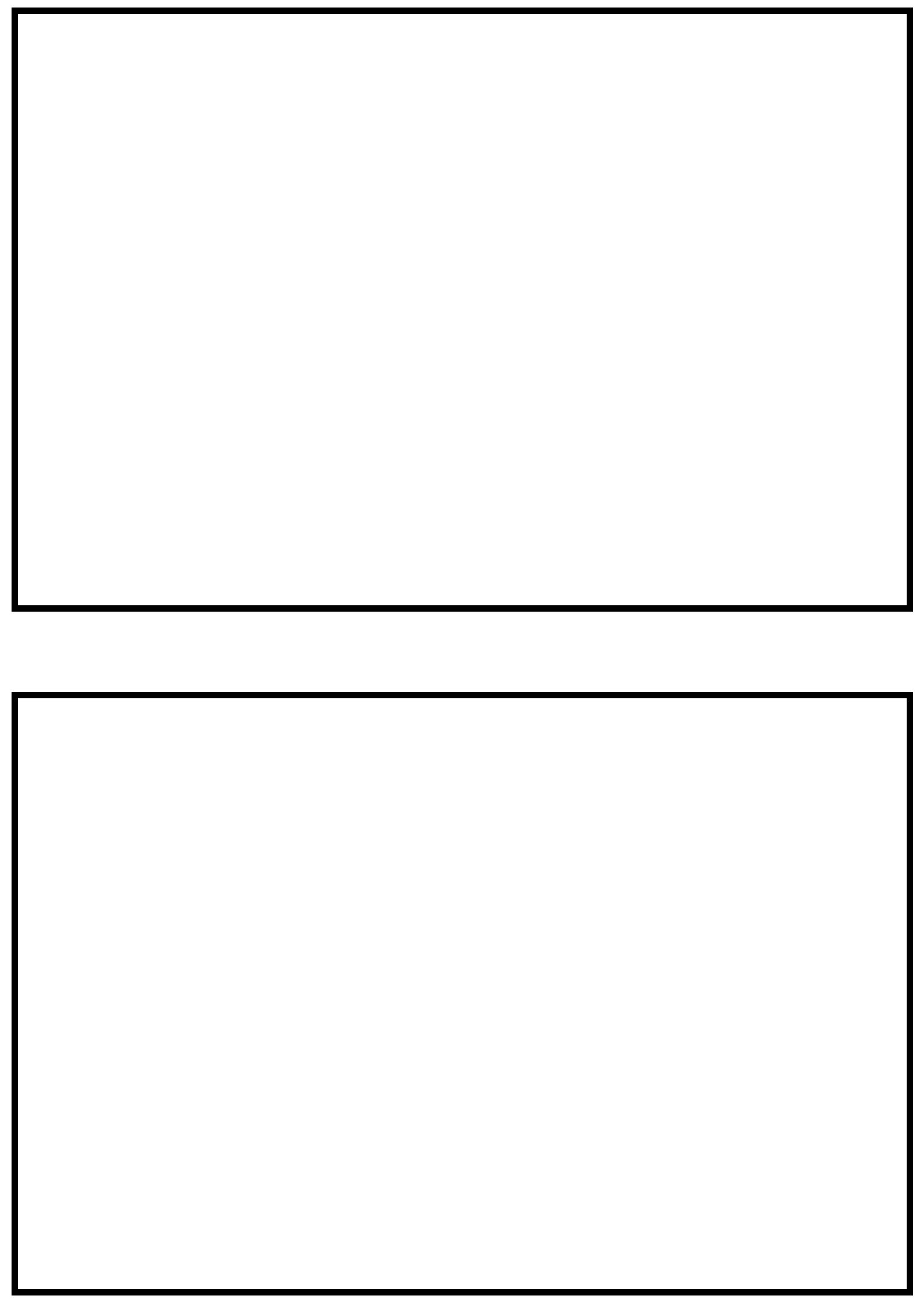

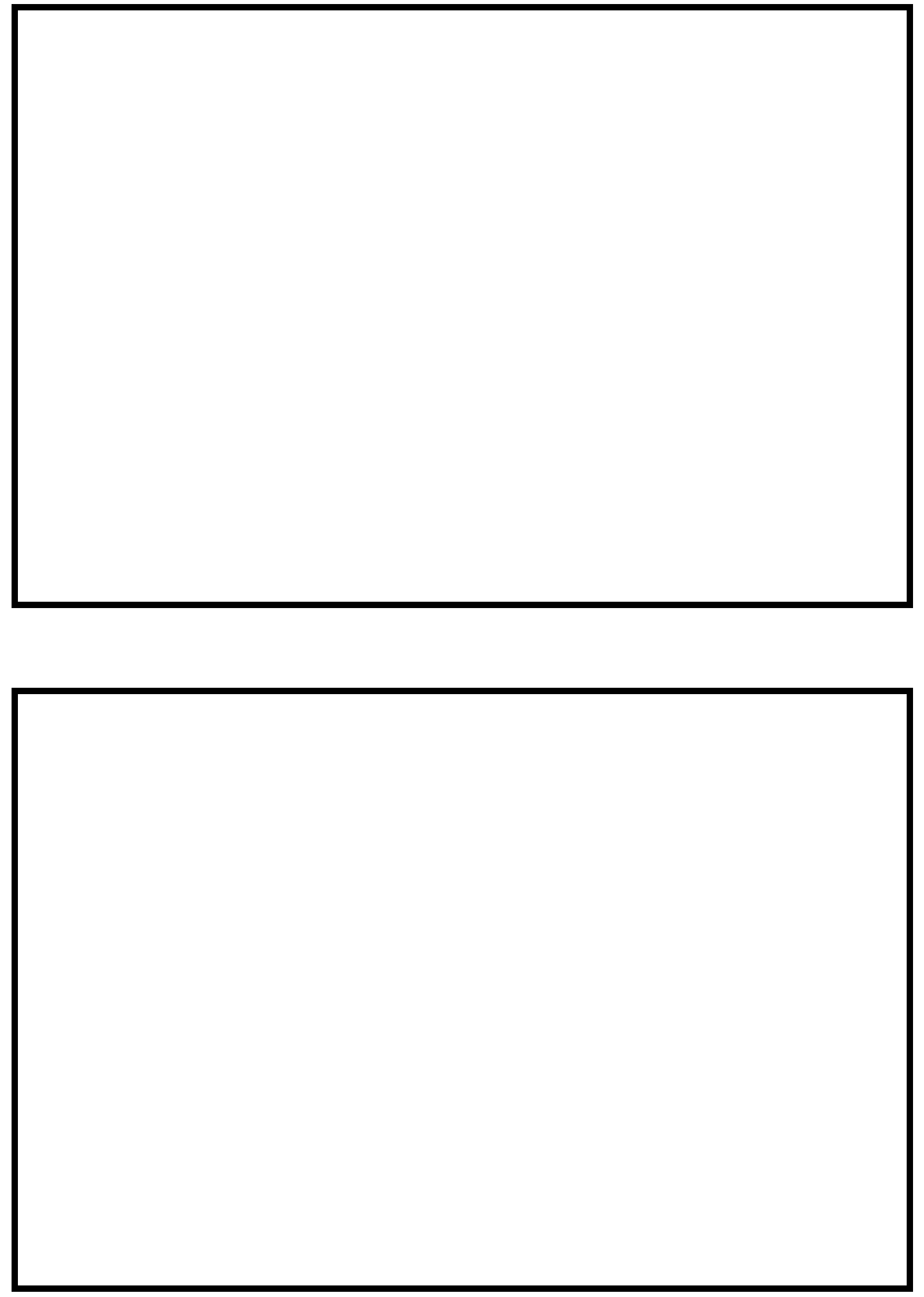


\section{LEVEL II SUMMARY}

\begin{tabular}{llllll} 
Structure Number & WFAITH00030007 & Stream & \multicolumn{3}{c}{ Algerine Brook } \\
& Orange & Road & TH 3 & District & 4
\end{tabular}

\section{Description of Bridge}



Abutments are concrete. The upstream wingwalls are

"laid-up" stone.

Yes

30

Is bridge skewed to flood flow according to No ' survey? Angle

There is a moderate channel bend in the upstream reach.

Debris accumulation on bridge at time of Level I or Level II site visit:

\begin{tabular}{|c|c|c|c|}
\hline & $\begin{array}{c}\text { Date of insnortion } \\
\underline{9 / 8 / 95}\end{array}$ & $\begin{array}{l}\text { Percent of alommal } \\
\text { blocked hortzontally }\end{array}$ & $\begin{array}{l}\text { Percent of a } 1 \text { ne } \\
\text { blocked verticatty }\end{array}$ \\
\hline & 9/8/95 & 0 & 0 \\
\hline
\end{tabular}

Level II

Moderate. There are some trees leaning over the channel upstream.

None as of 9/8/95.

Potential for debris

Doscriho anv fonturos noar ar at tho hridoo that mav, affort flow, (includo ahsorvation dato) 


\section{Description of the Geomorphic Setting}

General topography The channel is located within a moderate relief valley with steep valley walls on both sides.

Geomorphic conditions at bridge site: downstream (DS), upstream (US)

Date of inspection $\quad \underline{9 / 8 / 95}$

DS left: $\quad$ Steep channel to a narrow overbank.

DS right: $\quad$ Steep valley wall.

US left: $\quad$ Steep valley wall.

US right: $\quad$ Moderately sloped channel bank to a narrow overbank.

\section{Description of the Channel}

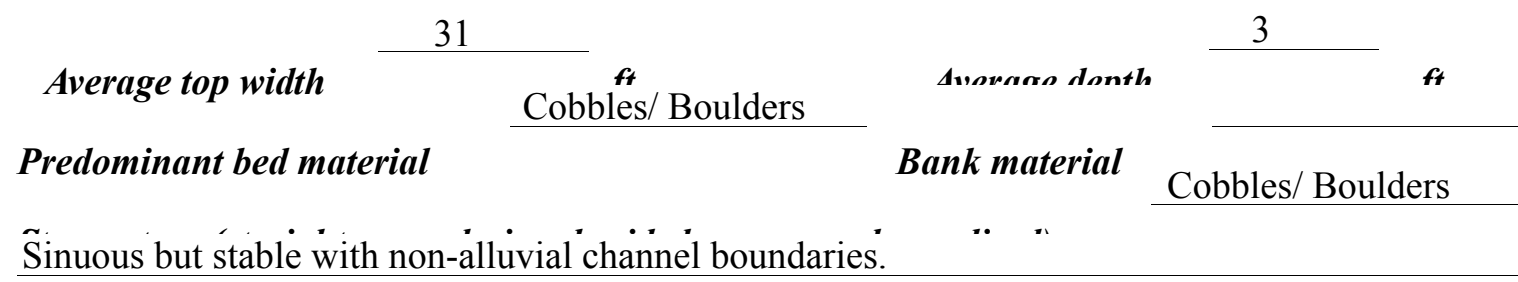



DS left: $\quad$ Trees and brush.

DS right: $\quad$ Trees and brush.

US left: $\quad$ Trees and brush.

US right: $\quad$ Yes

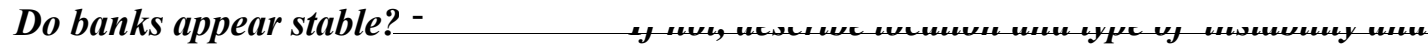

date of observatton.

None, 9/8/95.

Describe any obstructions in channel and date of observation. 


\title{
Hydrology
}

Drainage area $\frac{7.7}{m i^{2}}$

Percentage of drainage area in physiographic provinces: (approximate)

Physiographic province/section New England/New England Upland
Percent of drainage area 100

\begin{abstract}
Is drainage area considered rural or urban? Rural Describe any significant urbanization: None.
\end{abstract}

Is there a

Is there a USGS gage on the stream of interest? $--$

USGS gage description ---

USGS gage number

Gage drainage area $\mathrm{mi}^{2}$ No

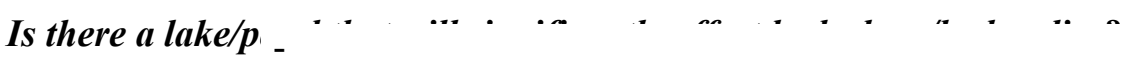

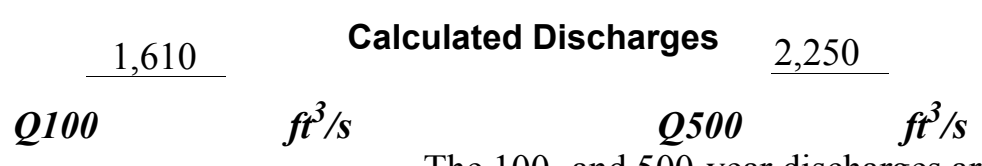

The 100- and 500-year discharges are based on a

method documented by the Federal Highway Administration (FHWA, 1983). The discharge values are within a range defined by several other empirical flood frequency curves (Benson, 1962; Johnson and Tasker, 1974; Potter, 1957a\&b; Talbot, 1887). 


\section{Description of the Water-Surface Profile Model (WSPRO) Analysis}

Datum for WSPRO analysis (USGS survey, sea level, VTAOT plans)

USGS survey

Datum tie between USGS survey and VTAOT plans

None.

Description of reference marks used to determine USGS datum. $\quad$ RM1 is a chiseled X in

bedrock on the US left bank, $70 \mathrm{ft}$ perpendicular to the culvert centerline between two jeep trails

(elev. $495.98 \mathrm{ft}$, arbitrary survey datum). RM2 is a nail $4.5 \mathrm{ft}$ above the ground in a telephone

pole (18-6-295), $120 \mathrm{ft}$ along the DS side of the right bank of TH $3,15 \mathrm{ft}$ from the edge of the

pavement (elev. $510.94 \mathrm{ft}$, arbitrary survey datum).

\section{Cross-Sections Used in WSPRO and CAP Analysis}

\begin{tabular}{cccl}
\hline${ }^{1}$ Cross-section & $\begin{array}{c}\text { Section } \\
\text { Reference } \\
\text { Distance } \\
\text { (SRD) in feet }\end{array}$ & $\begin{array}{c}{ }^{2} \text { Cross-section } \\
\text { development }\end{array}$ & \multicolumn{1}{c}{ Comments } \\
\hline EXITX & -21 & 1 & Exit section \\
FULLV & 0 & 2 & $\begin{array}{l}\text { Downstream Full-valley } \\
\text { section (Templated from } \\
\text { EXITX) }\end{array}$ \\
CLVRT & 0 & 1 & $\begin{array}{l}\text { Culvert outlet section } \\
\text { Approach section }\end{array}$ \\
APPRO & 109 & 1 &
\end{tabular}

${ }^{1}$ For location of cross-sections see plan-view sketch included with Level I field form, Appendix E. For more detail on how cross-sections were developed see WSPRO input file. 


\section{Data and Assumptions Used in WSPRO Model}

Hydraulic analyses of the reach were done by use of the Federal Highway Administration's one-dimensional, step-backwater computer program, WSPRO (Shearman and others, 1986, and Shearman, 1990) and the U.S. Geological Survey's Culvert Analysis Program (CAP, Fulford, 1995). The analyses reported herein reflect conditions existing at the site at the time of the study. Furthermore, in the development of the model it was necessary to assume no accumulation of debris or ice at the site. Although flow approaches this site at an angle greater than the opening-skew-to-roadway, flow was assumed to align with the abutments in the culvert. Results of the hydraulic model are presented in the Bridge Hydraulic Summary, appendix B, and figure 7 .

Channel roughness factors (Manning's " $n$ ") used in the hydraulic model were estimated using field inspections at each cross section following the general guidelines described by Arcement and Schneider (1989). Final adjustments to the values were made during the modelling of the reach. Channel " $\mathrm{n}$ " values for the reach ranged from 0.040 to 0.075 .

Normal depth at the exit section (EXITX) was assumed as the starting water surface. This depth was computed by use of the slope-conveyance method outlined in the user's manual for WSPRO (Shearman, 1990). The slope used was $0.0218 \mathrm{ft} / \mathrm{ft}$, which was estimated from surveyed points downstream of the bridge.

The approach section (APPRO) was surveyed one bridge length upstream of the upstream face as recommended by Shearman and others (1986). This location provides a consistent method for determining scour variables.

The unconstricted channel was modeled for each discharge by use of WSPRO. Then the water surface elevation computed at the FULLV section for each discharge under the unconstricted channel condition was applied as the starting water surface elevation for the culvert hydraulic analysis by use of the CAP. The CAP computes the appropriate discharge coefficient based on the techniques documented in Bodhaine (1968). 


\section{Bridge Hydraulics Summary}

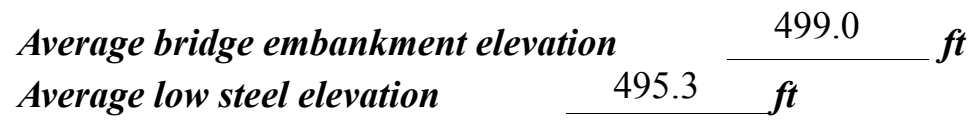

$$
\text { 100-year discharge } \quad 1,610 \quad \mathrm{ft}^{3} / \mathrm{s}
$$

Water-surface elevation in bridge opening $\quad 488.6 \quad f t$

Road overtopping? ___ No Discharge over road ___-- $\mathrm{ft}^{3} / \mathrm{s}$

Area of flow in bridge opening $\quad 134 \quad \mathrm{ft}^{2}$

Average velocity in bridge opening $12.0 \mathrm{ft} / \mathrm{s}$

Maximum WSPRO tube velocity at bridge $\quad--\quad \mathrm{ft} / \mathrm{s}$

Water-surface elevation at Approach section with bridge 493.6

Water-surface elevation at Approach section without bridge $\quad \overline{490.6}$

Amount of backwater caused by bridge $\quad 3.0$ it

500-year discharge $\quad 2,250 \quad \mathrm{ft}^{3} / \mathrm{s}$

Water-surface elevation in bridge opening $\quad 489.4$ ft

Road overtopping? ___ No Discharge over road ___ -- $\mathrm{ft}^{3} / \mathrm{s}$

Area of flow in bridge opening $\quad 149 \quad \mathrm{ft}^{2}$

Average velocity in bridge opening $\quad 15.1 \mathrm{ft} / \mathrm{s}$

Maximum WSPRO tube velocity at bridge $\quad{ }_{-} \quad$ _s

Water-surface elevation at Approach section with bridge $\quad 498.0$

Water-surface elevation at Approach section without bridge $\quad 491.5$

Amount of backwater caused by bridge $\quad 6.5$,t

Incipient overtopping discharge ___ -- $\mathrm{ft}^{3} / \mathrm{s}$

Water-surface elevation in bridge opening $\quad--\quad t$

Area of flow in bridge opening _ -- $\mathrm{ft}^{2}$

Average velocity in bridge opening __-- $\mathrm{ft} / \mathrm{s}$

Maximum WSPRO tube velocity at bridge _-- $\mathrm{ft} / \mathrm{s}$

Water-surface elevation at Approach section with bridge

Water-surface elevation at Approach section without bridge

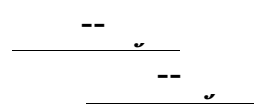

Amount of backwater caused by bridge _ 


\section{Scour Analysis Summary}

\section{Special Conditions or Assumptions Made in Scour Analysis}

Scour depths were computed using the general guidelines described in Hydraulic Engineering Circular 18 (Richardson and Davis, 1995). Scour depths were calculated assuming an infinite depth of erosive material and a homogeneous particle-size distribution. The results of the scour analyses for the 100- and 500-year discharges are presented in tables 1 and 2 and the scour depths are shown graphically in figure 8 .

Contraction scour for the 100- and 500-year discharges was computed by use of the Laursen clear-water contraction scour equation (Richardson and Davis, 1995, p. 32, equation 20). The computed streambed armoring depths suggest that armoring will not limit the depth of contraction scour.

Abutment scour was computed by use of the Froehlich equation (Richardson and Davis, 1995, p. 48, equation 28). Variables for the Froehlich equation include the Froude number of the flow approaching the embankments, the length of the embankment blocking flow, and the depth of flow approaching the embankment less any roadway overtopping. 


\section{Scour Results}

\section{0-yr discharge 500-yr discharge}

Contraction scour:

(Scour depths in feet)

Main channel

Live-bed scour

Clear-water scour

Depth to armoring

Left overbank

Right overbank

Local scour:

Abutment scour

Left abutment

11.3

14.9

$6.6-$

$11.2-$

Right abutment

Pier scour

Pier 1

Pier 2

Pier 3

\section{Abutments:}

Left abutment

Right abutment

Piers:

Pier 1

Pier 2

\section{Riprap Sizing}

Incipient overtopping 100-yr discharge 500-yrdischarge discharge

2.5

2.5

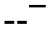

$--$


( $D_{50}$ in feet)

2.9 --

\section{9}

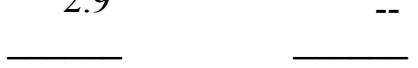

--

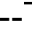

$--$

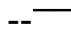






Figure 7. Water-surface profiles for the 100- and 500-yr discharges at structure WFAITH00030007 on Town Highway 3, crossing Algerine Brook, West Fairlee, Vermont. 


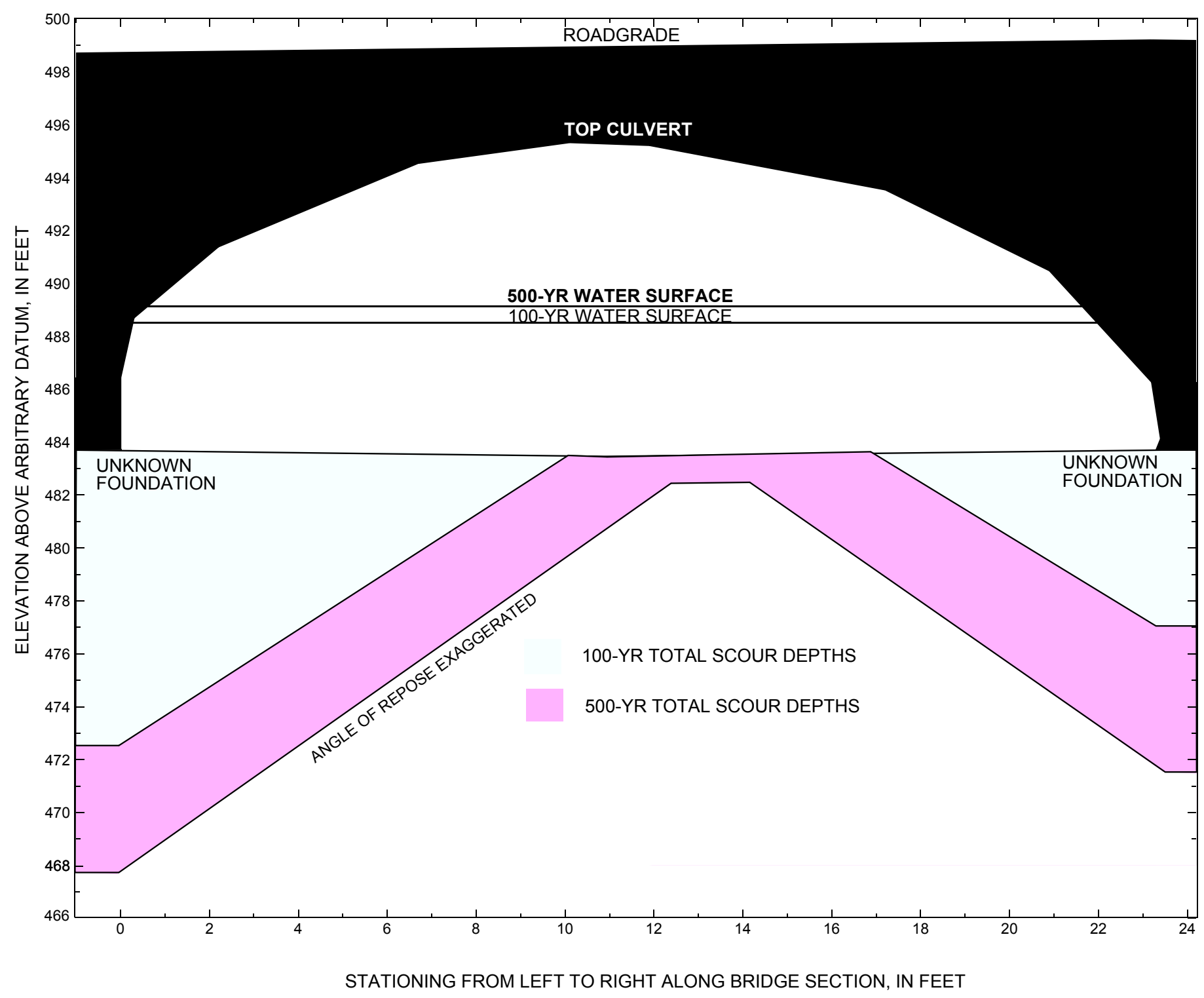

Figure 8. Scour elevations for the 100- and 500-yr discharges at structure WFAITH00030007 on Town Highway 3, crossing Algerine Brook, West Fairlee, Vermont. 
Table 1. Remaining footing/pile depth at abutments for the 100-yr discharge at structure WFAITH00030007 on Town Highway 3, crossing Algerine Brook, West Fairlee, Vermont.

[VTAOT, Vermont Agency of Transportation; --, no data]

\begin{tabular}{|c|c|c|c|c|c|c|c|c|c|c|c|}
\hline Description & Station $^{1}$ & $\begin{array}{l}\text { VTAOT } \\
\text { minimum } \\
\text { low-chord } \\
\text { elevation } \\
\text { (feet) }\end{array}$ & $\begin{array}{l}\text { Surveyed } \\
\text { minimum } \\
\text { low-chord } \\
\text { elevation }{ }^{2} \\
\text { (feet) }\end{array}$ & $\begin{array}{c}\text { Bottom of } \\
\text { footing } \\
\text { elevation } \\
\text { (feet) }\end{array}$ & $\begin{array}{c}\text { Channel } \\
\text { elevation at } \\
\text { abutment/ } \\
\text { pier }^{2} \\
\text { (feet) }\end{array}$ & $\begin{array}{l}\text { Contraction } \\
\text { scour depth } \\
\text { (feet) }\end{array}$ & $\begin{array}{l}\text { Abutment } \\
\text { scour } \\
\text { depth } \\
\text { (feet) }\end{array}$ & $\begin{array}{l}\text { Pier } \\
\text { scour } \\
\text { depth } \\
\text { (feet) }\end{array}$ & $\begin{array}{l}\text { Depth of } \\
\text { total scour } \\
\text { (feet) }\end{array}$ & $\begin{array}{c}\text { Elevation of } \\
\text { scour }^{2} \\
\text { (feet) }\end{array}$ & $\begin{array}{c}\text { Remaining } \\
\text { footing/pile } \\
\text { depth } \\
\text { (feet) }\end{array}$ \\
\hline \multicolumn{12}{|c|}{100 -yr discharge is 1,610 cubic-feet per second } \\
\hline Left abutment & 0.0 & -- & 495.3 & -- & 483.7 & 0.0 & 11.3 & -- & 11.3 & 472.4 & -- \\
\hline Right abutment & 23.4 & -- & 495.3 & -- & 483.7 & 0.0 & 6.6 & -- & 6.6 & 477.1 & -- \\
\hline
\end{tabular}

1.Measured along the face of the most constricting side of the bridge.

2.Arbitrary datum for this study.

Table 2. Remaining footing/pile depth at abutments for the 500-yr discharge at structure WFAITH00030007 on Town Highway 3, crossing Algerine Brook, West Fairlee, Vermont.

[VTAOT, Vermont Agency of Transportation; --, no data]

\begin{tabular}{|c|c|c|c|c|c|c|c|c|c|c|c|}
\hline Description & Station $^{1}$ & $\begin{array}{l}\text { VTAOT } \\
\text { minimum } \\
\text { low-chord } \\
\text { elevation } \\
\text { (feet) }\end{array}$ & $\begin{array}{c}\text { Surveyed } \\
\text { minimum } \\
\text { low-chord } \\
\text { elevation } \\
\text { (feet) }\end{array}$ & $\begin{array}{c}\text { Bottom of } \\
\text { footing } \\
\text { elevation } \\
\text { (feet) }\end{array}$ & $\begin{array}{c}\text { Channel } \\
\text { elevation at } \\
\text { abutment/ } \\
\text { pier }^{2} \\
\text { (feet) }\end{array}$ & $\begin{array}{l}\text { Contraction } \\
\text { scour depth } \\
\text { (feet) }\end{array}$ & $\begin{array}{c}\text { Abutment } \\
\text { scour } \\
\text { depth } \\
\text { (feet) }\end{array}$ & $\begin{array}{l}\text { Pier } \\
\text { scour } \\
\text { depth } \\
\text { (feet) }\end{array}$ & $\begin{array}{l}\text { Depth of } \\
\text { total scour } \\
\text { (feet) }\end{array}$ & $\begin{array}{c}\text { Elevation of } \\
\text { scour }^{2} \\
\text { (feet) }\end{array}$ & $\begin{array}{c}\text { Remaining } \\
\text { footing/pile } \\
\text { depth } \\
\text { (feet) }\end{array}$ \\
\hline \multicolumn{12}{|c|}{500 -yr discharge is 2,250 cubic-feet per second } \\
\hline Left abutment & 0.0 & -- & 495.3 & -- & 483.7 & 1.0 & 14.9 & -- & 15.9 & 467.8 & -- \\
\hline Right abutment & 23.4 & -- & 495.3 & -- & 483.7 & 1.0 & 11.2 & -- & 12.2 & 471.5 & -- \\
\hline
\end{tabular}

1.Measured along the face of the most constricting side of the bridge.

2.Arbitrary datum for this study. 


\section{SELECTED REFERENCES}

Arcement, G.J., Jr., and Schneider, V.R., 1989, Guide for selecting Manning's roughness coefficients for natural channels and flood plains: U.S. Geological Survey Water-Supply Paper 2339, 38 p.

Barnes, H.H., Jr., 1967, Roughness characteristics of natural channels: U.S. Geological Survey Water-Supply Paper 1849,213 p.

Benson, M. A., 1962, Factors Influencing the Occurrence of Floods in a Humid Region of Diverse Terrain: U.S. Geological Survey WaterSupply Paper 1580-B, 64 p.

Bodhaine, G. L., 1968, Measurement of Peak Discharge at Culverts by Indirect Methods: U.S. Geological Survey Techniques of Waterresources Investigations, Book 3, Chapter A3, 60 p.

Brown, S.A. and Clyde, E.S., 1989, Design of riprap revetment: Federal Highway Administration Hydraulic Engineering Circular No. 11, Publication FHWA-IP-89-016, 156 p.

Federal Highway Administration, 1983, Runoff estimates for small watersheds and development of sound design: Federal Highway Administration Report FHWA-RD-77-158.

Federal Highway Administration, 1993, Stream Stability and Scour at Highway Bridges: Participant Workbook: Federal Highway Administration Report FHWA-HI-91-011.

Federal Emergency Management Agency, 1982, Flood Insurance Study, Town of West Fairlee, Orange County, Vermont: Washington, D.C., December 2, 1982.

Froehlich, D.C., 1989, Local scour at bridge abutments in Ports, M.A., ed., Hydraulic Engineering--Proceedings of the 1989 National Conference on Hydraulic Engineering: New York, American Society of Civil Engineers, p. 13-18.

Fulford, J.M., 1995, User's Guide to the Culvert Analysis Program: U.S. Geological Survey Open-File Report $1995-137,69 \mathrm{p}$.

Hayes, D.C.,1993, Site selection and collection of bridge-scour data in Delaware, Maryland, and Virginia: U.S. Geological Survey WaterResources Investigation Report 93-4017, 23 p.

Interagency Advisory Committee on Water Data, 1982, Guidelines for determining flood flow frequency: U.S. Geological Survey, Bulletin 17B of the Hydrology Subcommittee, 190 p.

Johnson, C.G. and Tasker, G.D.,1974, Progress report on flood magnitude and frequency of Vermont streams: U.S. Geological Survey OpenFile Report 74-130, 37 p.

Lagasse, P.F., Schall, J.D., Johnson, F., Richardson, E.V., Chang, F., 1995, Stream Stability at Highway Structures: Federal Highway Administration Hydraulic Engineering Circular No. 20, Publication FHWA-IP-90-014, 144 p.

Laursen, E.M., 1960, Scour at bridge crossings: Journal of the Hydraulics Division, American Society of Civil Engineers, v. 86, no. HY2, p. 39-53.

Potter, W. D., 1957a, Peak rates of runoff in the Adirondack, White Mountains, and Maine woods area, Bureau of Public Roads

Potter, W. D., 1957b, Peak rates of runoff in the New England Hill and Lowland area, Bureau of Public Roads

Richardson, E.V. and Davis, S.R., 1995, Evaluating scour at bridges: Federal Highway Administration Hydraulic Engineering Circular No. 18, Publication FHWA-IP-90-017, 204 p.

Richardson, E.V., Simons, D.B., and Julien, P.Y., 1990, Highways in the river environment: Federal Highway Administration Publication FHWA-HI-90-016.

Ritter, D.F., 1984, Process Geomorphology: W.C. Brown Co., Debuque, Iowa, 603 p.

Shearman, J.O., 1990, User's manual for WSPRO--a computer model for water surface profile computations: Federal Highway Administration Publication FHWA-IP-89-027, 187 p.

Shearman, J.O., Kirby, W.H., Schneider, V.R., and Flippo, H.N., 1986, Bridge waterways analysis model; research report: Federal Highway Administration Publication FHWA-RD-86-108, 112 p.

Talbot, A.N., 1887, The determination of water-way for bridges and culverts.

U.S. Geological Survey, 1981, Vershire, Vermont 7.5 Minute Series quadrangle map: U.S. Geological Survey Topographic Maps, Photoinspected 1983, Scale 1:24,000. 


\section{APPENDIX A:}

WSPRO INPUT FILE 


\section{WSPRO INPUT FILE}






\section{APPENDIX B: \\ WSPRO OUTPUT FILE}


WSPRO OUTPUT FILE

CAP -USGS culvert analysis program VER 97-01

page 0

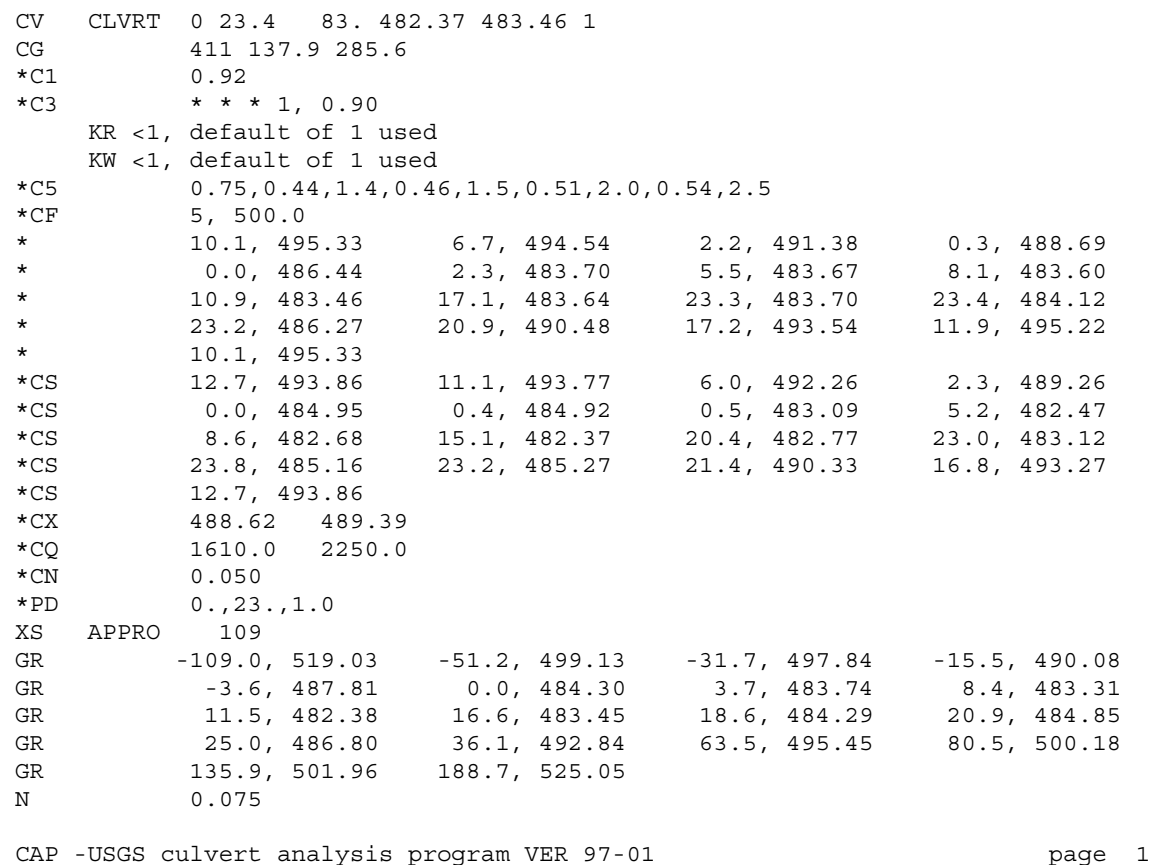

Hydraulic analysis for the culvert structure WFAITH00030007 CULVERT SECTION PROPERTIES - ID: CLVRT

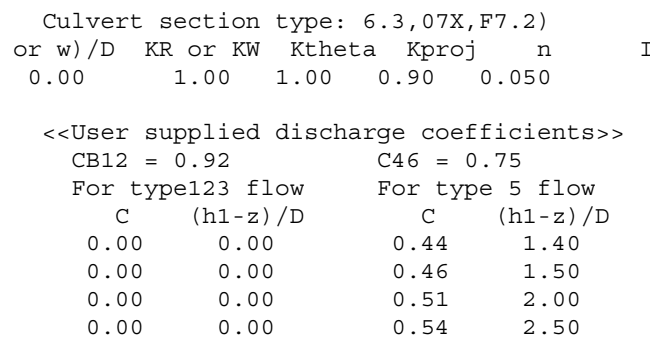

$\begin{array}{ccccc}\begin{array}{c}\text { Barrel } \\ \text { depth } \\ \text { (ft) }\end{array} & \begin{array}{c}\text { Area } \\ \text { (sq.ft) }\end{array} & \begin{array}{c}\text { Tonveyance } \\ \text { (cfs) }\end{array} & \begin{array}{c}\text { Tidth } \\ \text { (ft) }\end{array} & \begin{array}{c}\text { Wetted } \\ \text { perimeter } \\ \text { (ft) }\end{array} \\ 0.00 & 0.0 & 0.0 & 0.00 & 0.0 \\ 0.78 & 3.4 & 33.8 & 17.12 & 17.2 \\ 1.15 & 11.0 & 204.0 & 22.51 & 22.7 \\ 1.53 & 19.7 & 522.7 & 22.68 & 23.5 \\ 1.91 & 28.4 & 941.6 & 22.85 & 24.2 \\ 2.30 & 37.2 & 1443.7 & 23.02 & 25.0 \\ 2.68 & 46.1 & 2017.8 & 23.19 & 25.8 \\ 3.06 & 55.0 & 2634.0 & 23.70 & 27.0 \\ 3.45 & 63.9 & 3276.2 & 22.88 & 28.4 \\ 3.83 & 72.6 & 3974.2 & 22.54 & 29.2 \\ 4.21 & 81.2 & 4696.2 & 22.20 & 30.0 \\ 4.60 & 89.6 & 5436.5 & 21.86 & 30.9 \\ 4.98 & 97.9 & 6190.1 & 21.52 & 31.7 \\ 5.36 & 106.1 & 6952.9 & 21.18 & 32.6 \\ 5.74 & 114.2 & 7721.2 & 20.84 & 33.4 \\ 6.13 & 122.1 & 8492.0 & 20.50 & 34.2 \\ 6.51 & 129.9 & 9262.7 & 20.16 & 35.1 \\ 6.89 & 137.5 & 10030.8 & 19.82 & 35.9 \\ 7.28 & 145.1 & 10794.0 & 19.47 & 36.8 \\ 7.66 & 152.4 & 11509.1 & 18.87 & 37.8 \\ 8.04 & 159.5 & 12200.2 & 18.26 & 38.8 \\ 8.43 & 166.4 & 12851.2 & 17.55 & 39.9 \\ 8.81 & 172.9 & 13406.7 & 16.48 & 41.2 \\ 9.19 & 179.0 & 13909.5 & 15.40 & 42.5 \\ 9.57 & 184.7 & 14359.3 & 14.33 & 43.8 \\ 9.96 & 190.0 & 14755.9 & 13.26 & 45.1 \\ 10.34 & 194.8 & 15070.4 & 12.04 & 46.6 \\ 10.72 & 199.1 & 15178.2 & 10.15 & 48.7 \\ 11.11 & 202.6 & 15202.6 & 8.26 & 50.7 \\ 11.49 & 205.3 & 14931.8 & 5.25 & 53.8 \\ & 206.5 & 14158.6 & 0.00 & 59.2 \\ & & & & \end{array}$


WSPRO OUTPUT FILE (continued)

^LCAP -USGS culvert analysis program VER 97-01

page 2

Hydraulic analysis for the culvert structure WFAITH00030007

APPROACH SECTION PROPERTIES - ID: APPRO

\begin{tabular}{|c|c|c|c|c|c|}
\hline $\begin{array}{l}\text { Water } \\
\text { Surface } \\
\text { el.(ft) * }\end{array}$ & $\begin{array}{l}\text { Area } \\
(\text { sq.ft })\end{array}$ & $\begin{array}{c}\text { Conveyance } \\
\quad(\mathrm{cfs})\end{array}$ & $\begin{array}{c}\text { Top } \\
\text { width } \\
(\mathrm{ft})\end{array}$ & Alpha & $\begin{array}{l}\text { Critical } \\
\text { discharge } \\
\text { (cfs) }\end{array}$ \\
\hline 482.38 & 0.0 & 0.0 & 0.0 & 1.00 & 0.0 \\
\hline 483.34 & 3.7 & 43.6 & 8.0 & 1.00 & 14.4 \\
\hline 484.30 & 17.1 & 314.2 & 18.6 & 1.00 & 92.6 \\
\hline 485.26 & 37.1 & 991.7 & 22.7 & 1.00 & 268.9 \\
\hline 486.21 & 60.3 & 2029.5 & 25.7 & 1.00 & 524.0 \\
\hline 487.17 & 86.4 & 3407.6 & 28.6 & 1.00 & 851.5 \\
\hline 488.13 & 115.4 & 5027.2 & 32.7 & 1.00 & 1229.0 \\
\hline 489.09 & 150.0 & 6891.8 & 39.5 & 1.00 & 1658.0 \\
\hline 490.05 & 191.1 & 9310.7 & 46.3 & 1.00 & 2202.9 \\
\hline 491.01 & 237.3 & 12641.3 & 50.2 & 1.00 & 2929.7 \\
\hline 491.96 & 287.2 & 16522.2 & 53.9 & 1.00 & 3761.5 \\
\hline 492.92 & 340.7 & 20810.7 & 58.4 & 1.00 & 4670.4 \\
\hline 493.88 & 402.5 & 24392.0 & 70.5 & 1.00 & 5458.4 \\
\hline 494.84 & 475.8 & 29146.6 & 82.5 & 1.00 & 6482.5 \\
\hline 495.80 & 560.2 & 35624.8 & 92.2 & 1.00 & 7836.4 \\
\hline 496.76 & 651.1 & 44054.4 & 97.6 & 1.00 & 9542.5 \\
\hline 497.71 & 747.3 & 53449.6 & 103.1 & 1.00 & 11418.7 \\
\hline 498.67 & 853.2 & 60710.4 & 119.4 & 1.00 & 12944.8 \\
\hline 499.63 & 974.7 & 71304.0 & 131.2 & 1.00 & 15075.7 \\
\hline 500.59 & 1105.6 & 81171.5 & 148.7 & 1.00 & 17110.8 \\
\hline 501.55 & 1263.7 & 89286.8 & 181.3 & 1.00 & 18934.7 \\
\hline 502.51 & 1448.8 & 105791.8 & 198.1 & 1.00 & 22229.8 \\
\hline 503.46 & 1641.1 & 128008.0 & 203.1 & 1.00 & 26468.8 \\
\hline 504.42 & 1838.1 & 152083.3 & 208.1 & 1.00 & 30999.1 \\
\hline 505.38 & 2039.9 & 177997.1 & 213.1 & 1.00 & 35815.3 \\
\hline
\end{tabular}

*elevation referenced to common vertical datum

^LCAP -USGS culvert analysis program VER 97-01

Hydraulic analysis for the culvert structure WFAITH00030007



Abrevs. used: appr.-approach C-discharge coefficient eff.-effective

VH-velocity head alph-velocity coefficient n-Manning's roughness coef.

energy-specific energy F-Froude number entry, (1-2), (2-3)-part of reach 
WSPRO OUTPUT FILE (continued)

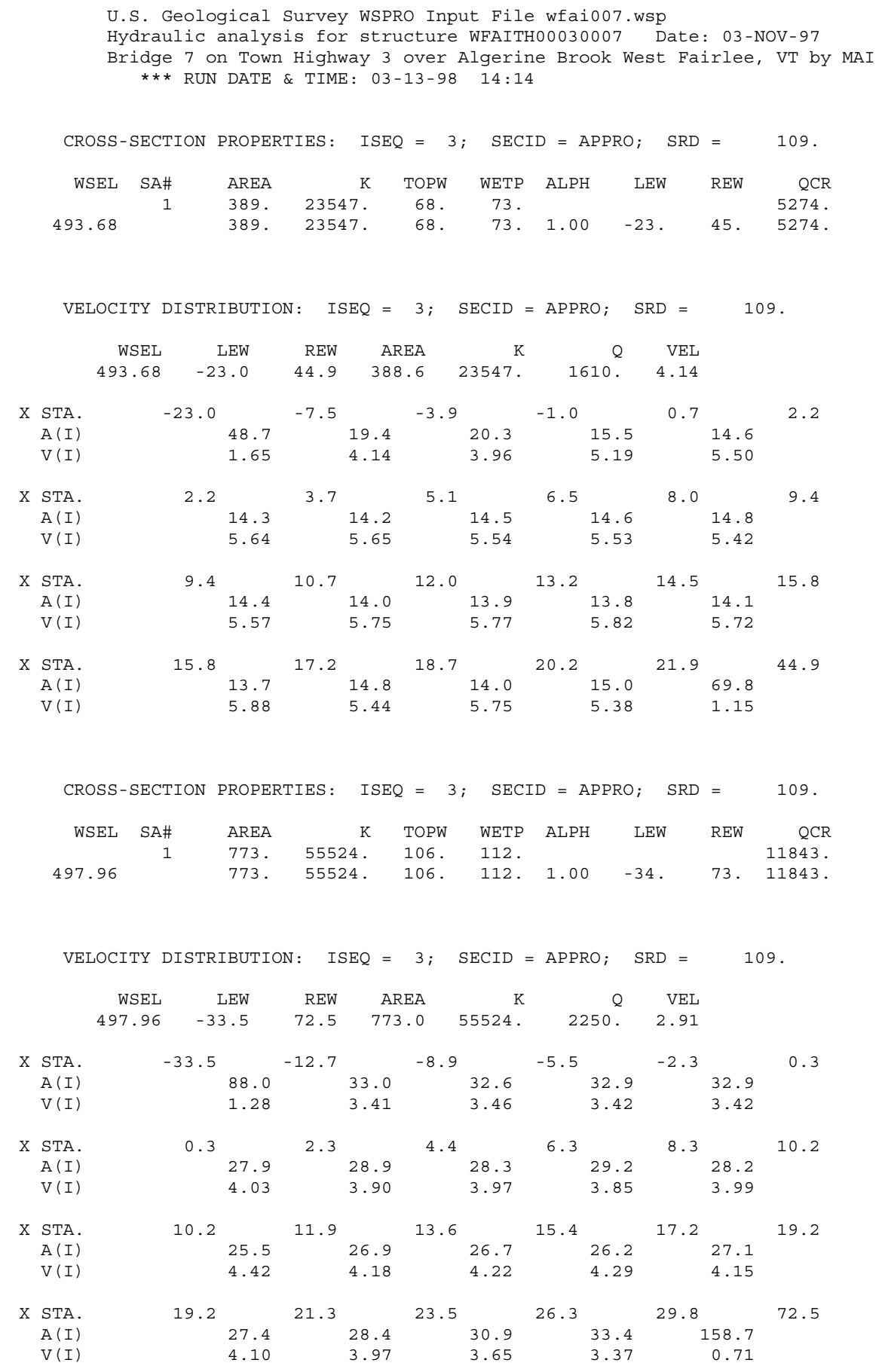


WSPRO OUTPUT FILE (continued)

U.S. Geological Survey WSPRO Input File wfaio07.wsp

Hydraulic analysis for structure WFAITH00030007 Date: 03-NOV-97

Bridge 7 on Town Highway 3 over Algerine Brook West Fairlee, VT by MAI *** RUN DATE \& TIME: 02-10-98 16:38

100-year discharge

\begin{tabular}{|c|c|c|c|c|c|c|c|c|c|}
\hline XSID : CODE & SRDL & LEW & AREA & VHD & $\mathrm{HF}$ & EGL & CRWS & $\mathrm{Q}$ & WSEL \\
\hline SRD & FLEN & REW & K & $\mathrm{ALPH}$ & $\mathrm{HO}$ & ERR & FR\# & VEL & \\
\hline EXITX:XS & $* * * * *$ & -15. & 211. & 0.90 & $\star \star \star \star \star *$ & 488.97 & 487.22 & 1610. & 488.06 \\
\hline$-21 . * *$ & $\star \star \star \star \star \star *$ & 53. & 10900. & 1.00 & $\star \star \star \star \star *$ &  & 0.77 & 7.63 & \\
\hline FULLV : XS & 21. & -17. & 234 . & 0.74 & 0.40 & 489.36 & $\star \star \star \star \star \star * \star * \star$ & 1610. & 488.62 \\
\hline 0 . & 21. & 54. & 12629. & 1.00 & 0.00 & 0.00 & 0.67 & 6.89 & \\
\hline$A P P R O: X S$ & 109. & -17. & 216. & 0.86 & 2.02 & 491.44 & 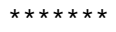 & 1610. & 490.58 \\
\hline $\begin{array}{c}109 . \\
\text { FIRST USER }\end{array}$ & $\begin{array}{l}109 \\
\text { DEFINED }\end{array}$ & $\begin{array}{l}32 . \\
\text { TABLE. }\end{array}$ & 11082 . & 1.00 & 0.06 & 0.00 & 0.62 & 7.45 & \\
\hline XSID : CODE & SRD & LEW & REW & & $\mathrm{Q}$ & $\mathrm{K}$ & AREA & VEL & WSEL \\
\hline EXITX:XS & -21 & -15 . & 53. & 161 & & 10900 . & 211. & 7.63 & 488.06 \\
\hline FULLV : XS & 0 . & -17. & 54. & 161 & & 12629. & 234. & 6.89 & 488.62 \\
\hline APPRO: XS & 109. & -17. & 32. & 161 & & 11082 . & 216. & 7.45 & 490.58 \\
\hline
\end{tabular}

SECOND USER DEFINED TABLE.

\begin{tabular}{|c|c|c|c|c|c|c|c|c|c|}
\hline XSID : CODE & CRWS & FR\# & YMIN & YMAX & $\mathrm{HF}$ & $\mathrm{HO}$ & VHD & EGL & WSEL \\
\hline EXITX:XS & 487.22 & 0.77 & 482.28 & 507.22 * & $* * * *$ & $\star \star \star \star \star *$ & 0.90 & 488.97 & 488.06 \\
\hline FULLV: XS & $\star * \star * \star * * * *$ & 0.67 & 482.52 & 507.46 & 0.40 & 0.00 & 0.74 & 489.36 & 488.62 \\
\hline APPRO:XS & 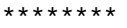 & 0.62 & 482.38 & 525.05 & 2.02 & 0.06 & 0.86 & 491.44 & 490.58 \\
\hline
\end{tabular}

500-year discharge

\begin{tabular}{|c|c|c|c|c|c|c|c|c|c|}
\hline XSID : CODE & SRDL & LEW & AREA & VHD & $\mathrm{HF}$ & EGL & CRWS & $Q$ & WSEL \\
\hline $\mathrm{SRD}$ & FLEN & REW & K & ALPH & HO & ERR & FR\# & VEL & \\
\hline XITX:XS & 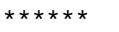 & -18. & 264 & 1.13 & $\star \star \star \star \star *$ & 489.94 & 488.24 & 2250 . & 488.81 \\
\hline-21 & 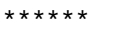 & 55. & 15229. & 1.00 & $\star * \star * *$ & $\star * \star * \star * \star *$ & 0.79 & 8.51 & \\
\hline FULLV : XS & 21. & -19. & 290. & 0.94 & 0.40 & 490.33 & 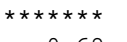 & 2250 & 489.39 \\
\hline 0 . & 21. & 55. & 17487. & 1.00 & 0.00 & -0.01 & 0.69 & 7.77 & \\
\hline $\begin{aligned} \text { PPRO }: X S \\
109 .\end{aligned}$ & $\begin{array}{l}109 . \\
109 .\end{array}$ & $\begin{array}{r}-18 \\
34\end{array}$ & $\begin{array}{r}262 . \\
14492 .\end{array}$ & $\begin{array}{l}1.15 \\
1.00\end{array}$ & $\begin{array}{l}2.18 \\
0.11\end{array}$ & $\begin{array}{r}492.63 \\
0.02\end{array}$ & $\begin{array}{r}\star \star \star \star \star \star \star \star * \\
0.68\end{array}$ & $\begin{array}{r}2250 \\
8.60\end{array}$ & 491.4 \\
\hline
\end{tabular}

FIRST USER DEFINED TABLE.

$\begin{array}{rrrrrrrrr}\text { XSID : CODE } & \text { SRD } & \text { LEW } & \text { REW } & Q & \text { K } & \text { AREA } & \text { VEL } & \text { WSEL } \\ \text { EXITX : XS } & -21 . & -18 . & 55 . & 2250 . & 15229 . & 264 . & 8.51 & 488.81 \\ \text { FULLV :XS } & 0 . & -19 . & 55 . & 2250 . & 17487 . & 290 . & 7.77 & 489.39 \\ \text { APPRO : XS } & 109 . & -18 . & 34 . & 2250 . & 14492 . & 262 . & 8.60 & 491.48\end{array}$

SECOND USER DEFINED TABLE.

$\begin{array}{lrrrrrrrrr}\text { XSID:CODE } & \text { CRWS } & \text { FR\# } & \text { YMIN } & \text { YMAX } & \text { HF } & \text { HO } & \text { VHD } & \text { EGL } & \text { WSEL } \\ \text { EXITX:XS } & 488.24 & 0.79 & 482.28 & 507.22 * * * * * * * * * * * & 1.13 & 489.94 & 488.81 \\ \text { FULLV:XS } & * * * * * * * & 0.69 & 482.52 & 507.46 & 0.40 & 0.00 & 0.94 & 490.33 & 489.39 \\ \text { APPRO:XS } & * * * * * * * * & 0.68 & 482.38 & 525.05 & 2.18 & 0.11 & 1.15 & 492.63 & 491.48\end{array}$


APPENDIX C:

BED-MATERIAL PARTICLE-SIZE DISTRIBUTION 


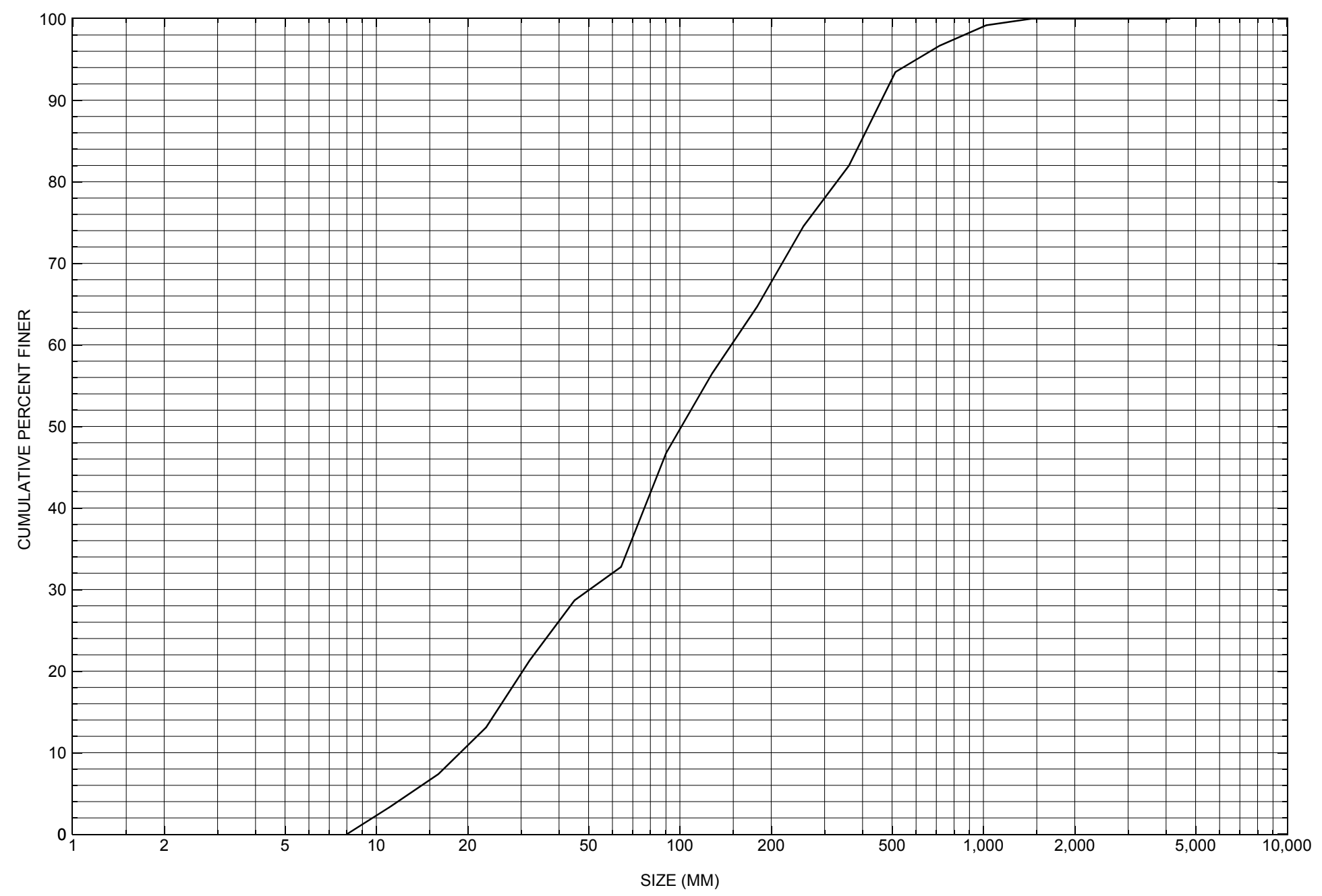

Appendix C. Bed material particle-size distribution for a pebble count in the channel approach of structure WFAITH00030007, in West Fairlee, Vermont. 


\section{APPENDIX D: \\ HISTORICAL DATA FORM}




\section{Structure Number WFAITH00030007}

\section{General Location Descriptive}

Data collected by (First Initial, Full last name) $\underline{\mathbf{E}}$. Boehmler

Date $(M M / D D / Y Y) \_\mathbf{0 3} / \underline{09} / \underline{95}$

Highway District Number (I - 2; nn) $\mathbf{0 4}$

Town (FIPS place code; I - 4; nnnnn) $\mathbf{7 9 9 7 5}$

Waterway (I - 6) Algerine (Coppermine) Brook

Route Number TH003

Topographic Map Vershire

Latitude (I - 16; nnnn.n) $\mathbf{4 3 5 4 7}$
County (FIPS county code; I - 3; nnn)

Mile marker (I - 11; nnn.nnn) $\mathbf{0 0 0 0 0 0}$

Road Name (I - 7): -

Vicinity (I - 9) $\mathbf{0 . 8 5}$ miles to jet with VT 113

Hydrologic Unit Code: $\mathbf{0 1 0 8 0 1 0 3}$

Longitude (i - 17; nnnnn.n) $\mathbf{7 2 1 6 7}$

\section{Select Federal Inventory Codes}

FHWA Structure Number (I - 8) 10091600070916

Maintenance responsibility $(I-21 ; n n) \quad \mathbf{0 3} \quad$ Maximum span length $(I-48 ; n n n n) \underline{\mathbf{0 0 2 5}}$

Year built (I - 27; YYYY) 1958

Structure length (I - 49; nnnnnn) $\underline{\mathbf{0 0 0 0 2 5}}$

Average daily traffic, ADT (I - 29; nnnnnn) 000350 Deck Width (I - 52; nn.n) $\mathbf{0 0 0}$

Year of ADT (I - 30; YY) $\mathbf{9 0}$

Channel \& Protection $(I-61 ; n) \underline{8}$

Opening skew to Roadway $(I-34 ; n n) \quad \mathbf{3 0}$

Waterway adequacy $(I-71 ; n) \underline{7}$

Operational status $(I-41 ; X) \mathbf{A}$

Underwater Inspection Frequency $(I-92 B ; X Y Y) \_\mathbf{N}$

Structure type (I - 43; nnn) 319

Year Reconstructed (I - 106) 1992

Approach span structure type $(I-44 ; n n n) \quad \mathbf{0 0 0}$ Clear span (nnn.nft) _ _

Number of spans (I - 45; nnn) $\mathbf{0 0 1}$

Vertical clearance from streambed (nnn.n ft) $\underline{\mathbf{1 2 . 0}}$

Number of approach spans (I - 46; nnnn) $\mathbf{0 0 0 0}$ Waterway of full opening $\left(n n n . n \mathrm{ft}^{2}\right)$ _

Comments:

The structural inspection report of 5/27/94 indicates the structure is a multi-plate arch crossing. This arch culvert was built in 1992 and no problems were reported. The streambed is noted as stone and gravel, except upstream of the culvert opening where some bedrock outcrops are present in the channel. 


\section{Bridge Hydrologic Data}

Is there hydrologic data available? $\underline{\mathbf{N}}$ if No, type ctrl-n $h \quad$ VTAOT Drainage area $\left(m i^{2}\right)$ : -

Terrain character:

Stream character \& type: -

Streambed material: Stone and gravel.

Discharge Data (cfs): $\quad Q_{2.33}-$

$$
\mathrm{Q}_{50}
$$

Record flood date (MM / DD / YY): -

Estimated Discharge (cfs):

Ice conditions (Heavy, Moderate, Light) : -

$\begin{array}{ll}Q_{10} \_- & Q_{25}- \\ Q_{100 \_-} & Q_{500}-\end{array}$

Water surface elevation (ft): -

The stage increases to maximum highwater elevation (Rapidly, Not rapidly):

The stream response is (Flashy, Not flashy):

Describe any significant site conditions upstream or downstream that may influence the stream's stage: -

Watershed storage area (in percent): - $\%$

The watershed storage area is: - (1-mainly at the headwaters; 2- uniformly distributed; 3-immediatly upstream oi the site)

Water Surface Elevation Estimates for Existing Structure:

\begin{tabular}{|l|l|l|l|l|l|}
\hline Peak discharge frequency & $Q_{2.33}$ & $Q_{10}$ & $Q_{25}$ & $Q_{50}$ & $Q_{100}$ \\
Water surface elevation (ft)) & - & - & - & - & - \\
Velocity (ft/sec) & - & - & - & - & - \\
\hline
\end{tabular}

Long term stream bed changes: -

Is the roadway overtopped below the $\mathrm{Q}_{100}$ ? (Yes, No, Unknown): $\mathbf{U} \quad$ Frequency: -

Relief Elevation (ft):

Discharge over roadway at $Q_{100}\left(f^{3} / \mathrm{sec}\right)$ :

Are there other structures nearby? (Yes, No, Unknown): $\mathbf{U}$ Upstream distance (miles): Town: If No or Unknown, type ctrl-n os Highway No. : Structure No. : Year Built:

Clear span (ft): Clear Height (ft): Full Waterway $\left(f^{2}\right)$ : 
Downstream distance (miles): Town: Year Built

Highway No. : Structure No. : Structure Type:

Clear span (ft): Clear Height $(f t)$ : Full Waterway $\left(f^{2}\right)$ : -

Comments:

\section{USGS Watershed Data}

Watershed Hydrographic Data

Drainage area (DA) 7.74 $\mathrm{mi}^{2}$ Lake/pond/swamp area 0.02 $\mathrm{mi}^{2}$

Watershed storage (ST) 0.3

Bridge site elevation 890 $\mathrm{ft}$ $\%$

Main channel length 3.75 mi

$10 \%$ channel length elevation 930 $\mathrm{ft} \quad 85 \%$ channel length elevation $\mathrm{ft}$

Main channel slope $(S)$
(S) 231.11 $\mathrm{ft} / \mathrm{mi}$

Watershed Precipitation Data

Average site precipitation in Average headwater precipitation in

Maximum 2yr-24hr precipitation event $(124,2)$ in

Average seasonal snowfall (Sn) $\mathrm{ft}$ 


\section{Bridge Plan Data}



Project Number

Minimum channel bed elevation:

Low superstructure elevation: USLAB DSLAB USRAB DSRAB Benchmark location description:

NO BENCHMARK INFORMATION.

Reference Point (MSL, Arbitrary, Other): _-

Datum (NAD27, NAD83, Other):

Foundation Type: 4

If 1: Footing Thickness

If 2: Pile Type:

If 3: Footing bottom elevation:

Is boring information available? $\mathbf{N}$

Foundation Material Type: $\mathbf{3}$

(1-Spreadfooting; 2-Pile; 3- Gravity; 4-Unknown)

Footing bottom elevation: -

Briefly describe material at foundation bottom elevation or around piles:

NO FOUNDATION MATERIAL INFORMATION.

Comments:

The plans that are available are those for the original structure. No plans exist for the current multi-plate arch structure. 


\section{Cross-sectional Data}

Is cross-sectional data available? No If no, type ctrl-n xs

Source (FEMA, VTAOT, Other)? Comments:

\section{NO CROSS SECTION INFORMATION}

\begin{tabular}{|l|l|l|l|l|l|l|l|l|l|l|l|}
\hline Station & - & - & - & - & - & - & - & - & - & - & - \\
\hline Feature & - & - & - & - & - & - & - & - & - & - & - \\
\hline $\begin{array}{l}\text { Low chord } \\
\text { elevation }\end{array}$ & - & - & - & - & - & - & - & - & - & - & - \\
\hline $\begin{array}{l}\text { Bed } \\
\text { elevation }\end{array}$ & - & - & - & - & - & - & - & - & - & - & - \\
\hline $\begin{array}{l}\text { Low chord } \\
\text { to bed }\end{array}$ & - & - & - & - & - & - & - & - & - & - & - \\
\hline Station & - & - & - & - & - & - & - & - & - & - & - \\
\hline Feature & - & - & - & - & - & - & - & - & - & - & - \\
\hline $\begin{array}{l}\text { Low chord } \\
\text { elevation }\end{array}$ & - & - & - & - & - & - & - & - & - & - & - \\
\hline $\begin{array}{l}\text { Bed } \\
\text { elevation }\end{array}$ & - & - & - & - & - & - & - & - & - & - & - \\
\hline $\begin{array}{l}\text { Low chord } \\
\text { to bed }\end{array}$ & - & - & - & - & - & - & - & - & - & - & - \\
\hline
\end{tabular}

Source (FEMA, VTAOT, Other)?

Comments: NO CROSS SECTION INFORMATION

\begin{tabular}{|l|l|l|l|l|l|l|l|l|l|l|l|}
\hline Station & - & - & - & - & - & - & - & - & - & - & - \\
\hline Feature & - & - & - & - & - & - & - & - & - & - & - \\
\hline $\begin{array}{l}\text { Low chord } \\
\text { elevation }\end{array}$ & - & - & - & - & - & - & - & - & - & - & - \\
\hline $\begin{array}{l}\text { Bed } \\
\text { elevation }\end{array}$ & - & - & - & - & - & - & - & - & - & - & - \\
\hline $\begin{array}{l}\text { Low chord } \\
\text { to bed }\end{array}$ & - & - & - & - & - & - & - & - & - & - & - \\
\hline Station & - & - & - & - & - & - & - & - & - & - & - \\
\hline Feature & - & - & - & - & - & - & - & - & - & - & - \\
\hline $\begin{array}{l}\text { Low chord } \\
\text { elevation }\end{array}$ & - & - & - & - & - & - & - & - & - & - & - \\
\hline $\begin{array}{l}\text { Bed } \\
\text { elevation }\end{array}$ & - & - & - & - & - & - & - & - & - & - & - \\
\hline $\begin{array}{l}\text { Low chord } \\
\text { to bed }\end{array}$ & - & - & - & - & - & - & - & - & - & - & - \\
\hline
\end{tabular}


APPENDIX E:

LEVEL I DATA FORM 
U. S. Geological Survey

Bridge Field Data Collection and Processing Form

Qa/Qc Check by: RB Date: $2 / 22 / 96$

\section{Structure Number}

WFAITH00030007

Computerized by: $\underline{\mathbf{R B}}$ Date: $2 / 22 / 96$

Reviewd by:

MAI Date: $\underline{11 / 18 / 97}$

\section{A. General Location Descriptive}

1. Data collected by (First Initial, Full last name) $\underline{\mathbf{E}}$. Boehmler

2. Highway District Number $\mathbf{4}$

County Orange (017)

Waterway (I - 6) Algerine (Coppermine) Brook

Route Number TH 3

Date $(M M / D D / Y Y) \underline{9} / \underline{8} / \underline{1995}$

Mile marker $\mathbf{0}$

Town West Fairlee (79975)

Road Name Beanville Road

Hydrologic Unit Code: $\mathbf{0 1 0 8 0 1 0 3}$

3. Descriptive comments:

The site is located $\mathbf{0 . 8 5}$ miles from State Route 113.

\section{B. Bridge Deck Observations}
4. Surface cover... LBUS 6
RBUS 6
LBDS 6
RBDS 6
Overall 6

(2b us,ds,lb,rb: 1- Urban; 2- Suburban; 3- Row crops; 4- Pasture; 5- Shrub- and brushland; 6- Forest; 7- Wetland)
5. Ambient water surface... US 2
UB 2
DS 2
(1- pool; 2- riffle)

6. Bridge structure type 3 (1- single span; 2- multiple span; 3- single arch; 4- multiple arch; 5-cylindrical culvert; 6- box culvert; or 7- other)

7. Bridge length 25.0 (feet)

Road approach to bridge:
8. LB 1
RB 2
( 0 even, 1- lower, 2- higher)
9. LB
RB 1
(1- Paved, 2- Not paved)

10. Embankment slope (run / rise in feet / foot)

US left

US right

\begin{tabular}{|c|c|c|c|}
\hline \multicolumn{2}{|c|}{ Protection } & \multirow{2}{*}{ 13.Erosion } & 14.Severity \\
\hline 11.Type & 12.Cond. & $\mathbf{0}$ & $\mathbf{0}$ \\
\hline $\mathbf{0}$ & - & $\underline{\mathbf{0}}$ & $\mathbf{1}$ \\
\hline $\mathbf{0}$ & - & $\mathbf{2}$ & $\mathbf{0}$ \\
\hline $\mathbf{5}$ & $\mathbf{1}$ & $\mathbf{0}$ & $\mathbf{0}$ \\
\hline $\mathbf{5}$ & $\mathbf{1}$ & $\mathbf{0}$ & $\mathbf{0}$ \\
\hline
\end{tabular}

Bank protection types: 0- none; 1- < 12 inches;

2- < 36 inches; 3- < 48 inches;

4- < 60 inches; 5- wall / artificial levee

Bank protection conditions: 1- good; 2- slumped;

3- eroded; 4- failed

Erosion: 0 - none; 1- channel erosion; 2 -

road wash; 3- both; 4- other

Erosion Severity: 0 - none; 1- slight; 2- moderate; 3- severe

Span length $\underline{\mathbf{2 5 . 0}}$ (feet) Bridge width

\section{Channel approach to bridge (BF):}

15. Angle of approach: $\mathbf{0}$

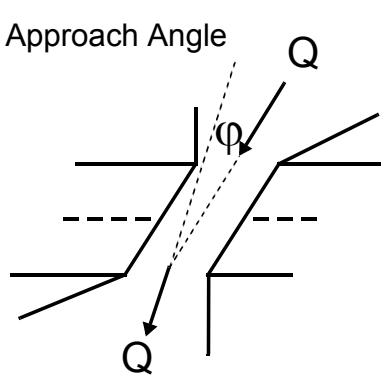

17. Channel impact zone 1 :

Where? LB $(L B, R B)$

Range? 85 feet US

Channel impact zone 2:

Where? RB (LB, RB)

Range? 130 feet $\underline{\mathbf{D S}}$ (US, UB, DS) to $\underline{195}$ feet $\underline{\mathbf{D S}}$

Impact Severity: 0- none to very slight; 1- Slight; 2- Moderate; 3- Severe
16. Bridge skew: $\mathbf{3 0}$ Bridge Skew Angle

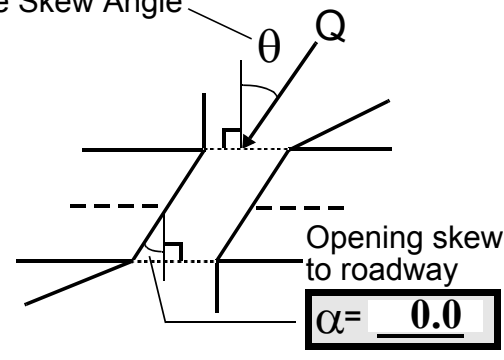

\section{Exist? $\underline{\mathbf{Y}}(\mathrm{Y}$ or $N)$}

Severity $\underline{3}$

, UB, DS) to $\underline{65}$ feet $\underline{\mathbf{U S}}$

Exist? $\mathbf{Y}(Y$ or $N)$

Severity 1 
18. Bridge Type: $\mathbf{1 a} / \mathbf{1 b}$

1a- Vertical abutments with wingwalls

1 b- Vertical abutments without wingwalls

2- Vertical abutments and wingwalls, sloping embankment Wingwalls parallel to abut. face

3- Spill through abutments

4- Sloping embankment, vertical wingwalls and abutments

Wingwall angle less than $90^{\circ}$.



19. Bridge Deck Comments (surface cover variations, measured bridge and span lengths, bridge type variations, approach overflow width, etc.)

The structure is a multiplate arch culvert with wingwalls at the US end and no wingwalls DS. The culvert opening measured 25 feet wide at the base of the plates where they meet the concrete footings. The surface cover is all forest except for small grass plots near the culvert orifices at each end. The roadway width or crest for weir flow, is 20.2 feet. While the left bank impact is severe due to a 90 degree bend right in the channel, the left bank is bedrock.

\section{Upstream Channel Assessment}

\begin{tabular}{|c|c|c|c|c|c|c|c|c|c|c|c|}
\hline \multicolumn{5}{|c|}{ 21. Bank height (BF) 22. Bank angle (BF) } & \multicolumn{2}{|c|}{ 26. \% Veg. cover (BF) } & \multicolumn{3}{|c|}{ 27. Bank material (BF) } & \multicolumn{2}{|c|}{ 28. Bank erosion (BF) } \\
\hline 20. SRD & LB & RB & LB & $\mathrm{RB}$ & LB & RB & LB & RB & & LB & RB \\
\hline 25.0 & 3 & & & 2.5 & 4 & 3 & 6 & 45 & & 1 & $\mathbf{0}$ \\
\hline \multicolumn{2}{|c|}{ 23. Bank width } & 45.0 & 24. & lel width & 20.0 & 25. Tha & Iweg dep & 28.5 & \multicolumn{3}{|c|}{ 29. Bed Material $\mathbf{5 6 4}$} \\
\hline \multicolumn{3}{|c|}{30 .Bank protection type: } & LB $\underline{0}$ & RB 3 & & 31. Bank $p$ & otection & dition: & LB - & & \\
\hline \multicolumn{12}{|c|}{  } \\
\hline
\end{tabular}

32. Comments (bank material variation, minor inflows, protection extent, etc.):

The channel US extends straight US from the culvert entrance then makes a 90 degree bend centered on $80 \mathrm{ft}$ US of the culvert. The 90 degree bend follows the joint geometry and configuration of the bedrock on the left bank US. The bedrock extends around the bend to $98 \mathrm{ft}$ US and ends about $4 \mathrm{ft}$ US of the culvert entrance. It also forms part of the bed material mainly on the left bank side of the channel. The bedrock only visibly crosses the channel in the area of $25 \mathrm{ft}$ US to $50 \mathrm{ft}$ US. There is a higher than usual silt clay fraction to the material particularly on the right bank and right bank side of the channel. The right bank is protected from $15 \mathrm{ft}$ US at the end of the stone wingwall and $35 \mathrm{ft} \mathrm{US}$. 
33.Point/Side bar present? Y $(Y$ or $N$. if $N$ type ctrl-n pb)/34. Mid-bar distance: 48

35. Mid-bar width: $\mathbf{5 . 5}$

36. Point bar extent: $\underline{\mathbf{6 2}}$ feet $\underline{\mathrm{US}}$ (US, UB) to $\underline{\mathbf{3 5}}$ feet $\underline{\mathrm{US}}$ (US, UB, DS) positioned $\underline{\mathbf{9 0}} \%$ LB to $\underline{\mathbf{1 0 0}} \% \mathrm{RB}$

37. Material: 35

38. Point or side bar comments (Circle Point or Side; Note additional bars, material variation, status, etc.):

A small unvegetated side bar composed primarily of fine to medium gravel, some silt, clay, and sand deposited on top of boulders and bedrock.

39. Is a cut-bank present? $\mathbf{N}$ ( $Y$ or if $N$ type ctrl-n $c b)$

40. Where? - $(L B$ or $R B)$

41. Mid-bank distance: -

42. Cut bank extent: -

feet -

(US, UB) to feet (US, UB, DS)

43. Bank damage: -

(1- eroded and/or creep; 2- slip failure; 3- block failure)

44. Cut bank comments (eg. additional cut banks, protection condition, etc.):

NO CUT BANKS

45. Is channel scour present? $\mathbf{N}$ ( $Y$ or if $N$ type ctrl-n cs) 46. Mid-scour distance: -

47. Scour dimensions: Length -

Width -

Depth : -

Position -

$\%$ LB to $\% \mathrm{RB}$

48. Scour comments (eg. additional scour areas, local scouring process, etc.):

NO CHANNEL SCOUR Some small pools have developed in the bedrock between $60 \mathrm{ft}$ US and $40 \mathrm{ft} \mathrm{US \text {, }}$ and between $35 \mathrm{ft} U S$ and $40 \mathrm{ft}$ US which are slightly deeper than the thalweg depths elsewhere, at most 0.5 to $0.8 \mathrm{ft}$ deeper. Bedrock has formed 2 small water falls US at $35 \mathrm{ft}$ US and $60 \mathrm{ft}$ US with a pool below each but no abnormal erosion.

\section{Are there major confluences? $\mathbf{N}$}

51. Confluence 1: Distance -

Confluence 2: Distance -

52. Enters on -

Enters on -

54. Confluence comments (eg. confluence name):

NO MAJOR CONFLUENCES
50. How many? -

53. Type (1-perennial; 2- ephemeral)

Type (1- perennial; 2- ephemeral) ( $(L B$ or $R B)$

\section{Under Bridge Channel Assessment}

55. Channel restraint (BF)? LB 2

\begin{tabular}{|ccc}
\hline \multicolumn{2}{|c}{ 56. Height (BF) } & \multicolumn{2}{c}{57 Angle } \\
LB & RB & LB \\
$\mathbf{1 8 . 5}$ & & \\
\hline
\end{tabular}

58. Bank width (BF) (1- natural bank; 2- abutment; 3- artificial levee)

Bed and bank Material: 0- organics; 1- silt / clay, < 1/16mm; 2- sand, 1/16 - 2mm; 3- gravel, 2 - 64mm; 4- cobble, 64 - 256mm; 5- boulder, > 256mm; 6- bedrock; 7- manmade

Bank Erosion: 0- not evident; 1- light fluvial; 2- moderate fluvial; 3- heavy fluvial / mass wasting

64. Comments (bank material variation, minor inflows, protection extent, etc.):

451 
65. Debris and Ice Is there debris accumulation?

$(Y$ or $N)$ 66. Where? $\mathbf{N}$

(1- Upstream; 2- At bridge; 3-Both)

67. Debris Potential ( 1- Low; 2- Moderate; 3- High)

68. Capture Efficiency 2

(1-Low; 2- Moderate; 3- High)

69. Is there evidence of ice build-up? 2 (Y or $N)$

Ice Blockage Potential $\mathbf{N}$

(1-Low; 2-Moderate; 3- High)

70. Debris and Ice Comments:

2

Debris and ice are likely to build up at the 90 degree bend US, the bedrock in the channel, and on the left bank. The banks are stable for the most part, but with forest all around on each bank US, the potential for debris generation in the channel is moderate.

\begin{tabular}{|l|c|c|c|c|c|c|c|c|}
\hline Abutments & $\begin{array}{c}\text { 71. Attack } \\
\angle \text { (BF) }\end{array}$ & $\begin{array}{c}\text { 72. Slope } \angle \\
\text { (Qmax) }\end{array}$ & $\begin{array}{c}\text { 73. Toe } \\
\text { loc. (BF) }\end{array}$ & $\begin{array}{c}\text { 74. Scour } \\
\text { Condition }\end{array}$ & $\begin{array}{c}\text { 75. Scour } \\
\text { depth }\end{array}$ & $\begin{array}{c}\text { 76. Exposure } \\
\text { depth }\end{array}$ & 77. Material & 78. Length \\
\hline LABUT & & $\mathbf{0}$ & $\mathbf{9 0}$ & $\mathbf{2}$ & $\mathbf{2}$ & $\mathbf{0}$ & $\mathbf{2}$ & $\mathbf{9 0 . 0}$ \\
\hline RABUT & $\mathbf{1}$ & - & $\mathbf{9 0}$ & & & $\mathbf{2}$ & $\mathbf{2}$ & $\mathbf{2 3 . 0}$ \\
\hline
\end{tabular}

Pushed: $L B$ or RB

Toe Location (Loc.): 0- even, 1- set back, 2- protrudes

Scour cond.: 0- not evident; 1- evident (comment); 2- footing exposed; 3-undermined footing; 4- piling exposed; 5- settled; 6- failed

Materials: 1- Concrete; 2- Stone masonry or drywall; 3- steel or metal; 4- wood

79. Abutment comments (eg. undermined penetration, unusual scour processes, debris, etc.):

0

2

1

The abutments are concrete at the base then the corrugated metal is sealed into the concrete on each side. The concrete portion, footing, is exposed on both sides for their entire length.

80. Wingwalls:



USLWW:



Wingwall materials: 1- Concrete; 2- Stone masonry or drywall; 3- steel or metal; 4- wood



82. Bank / Bridge Protection:

\begin{tabular}{|l|l|l|l|l|l|l|c|c|}
\hline Location & USLWW & USRWW & LABUT & RABUT & LB & RB & DSLWW & DSRWW \\
\hline Type & $\mathbf{0}$ & - & $\mathbf{N}$ & - & - & - & - & - \\
\hline Condition & $\mathbf{N}$ & - & - & - & - & - & - & - \\
\hline Extent & - & - & - & $\mathbf{0}$ & $\mathbf{0}$ & $\mathbf{0}$ & $\mathbf{0}$ & - \\
\hline
\end{tabular}

Bank / Bridge protection types: 0- absent; 1- < 12 inches; 2- < 36 inches; 3- < 48 inches; 4- < 60 inches; 
83. Wingwall and protection comments (eg. undermined penetration, unusual scour processes, etc.):

-
-
-
-
-
-
-
-
-

\section{Piers:}

84. Are there piers? Th (Y or if $N$ type ctrl-n pr)

\begin{tabular}{|l|l|l|l|l|l|l|l|}
\hline \multirow{2}{*}{$\begin{array}{l}85 . \\
\text { Pier no. }\end{array}$} & \multicolumn{3}{|c|}{ width (w) feet } & \multicolumn{3}{c|}{ elevation (e) feet } \\
\cline { 2 - 9 } & w1 & w2 & w3 & e@w1 & e@w2 & e@w3 \\
\hline Pier 1 & & $\mathbf{6 . 0}$ & & $\mathbf{2 0 . 0}$ & $\mathbf{7 0 . 0}$ & $\mathbf{1 3 . 5}$ \\
\hline Pier 2 & - & - & - & - & - & - \\
\hline Pier 3 & - & - & - & - & - & - \\
\hline Pier 4 & - & - & - & - & - & - \\
\hline
\end{tabular}

\begin{tabular}{|l|l|l|l|l|}
\hline Level 1 Pier Descr. & \multicolumn{1}{|c|}{1} & \multicolumn{1}{|c|}{2} & 3 & \multicolumn{1}{|c|}{} \\
\hline 86. Location (BF) & e wing- & n. & - & - \\
\hline 87. Type & walls & & - & - \\
\hline 88. Material & are & & - & - \\
\hline 89. Shape & unpr & & - & - \\
\hline 90. Inclined? & otect & & - & - \\
\hline 91. Attack $\angle$ (BF) & ed & & - & - \\
\hline 92. Pushed & but & & - & - \\
\hline 93. Length (feet) & - & - & - & - \\
\hline 94. \# of piles & appe & & - & - \\
\hline 95. Cross-members & ar in & & - & - \\
\hline 96. Scour Condition & good & & - & - \\
\hline 97. Scour depth & con- & & - & - \\
\hline 98. Exposure depth & ditio & N & - & - \\
\hline
\end{tabular}

LFP, LTB, LB, MCL, MCM, MCR, RB, RTB, RFP

1- Solid pier, 2- column, 3- bent

1-Wood; 2- concrete; 3- metal; 4- stone

1- Round; 2- Square; 3- Pointed

Y-yes; $N-$ no

$L B$ or $R B$

0- none; 1- laterals; 2- diagonals; 3- both

0- not evident; 1- evident (comment);

2- footing exposed; 3- piling exposed;

4- undermined footing; 5- settled; 6- failed 
99. Pier comments (eg. undermined penetration, protection and protection extent, unusual scour processes, etc.):

-
-
-
-
-
-
-
-
-
-

100.

\section{E. Downstream Channel Assessment}



Comments (eg. bank material variation, minor inflows, protection extent, etc.):

$$
-
$$

$-$

$-$

\section{NO PIERS}

101. Is a drop structure present? 7 ( $Y$ or $N$, if $N$ type ctrl-n ds) 102. Distance: _ _ feet 103. Drop: - feet 104. Structure material: $\mathbf{5 1 4}$ (1- steel sheet pile; 2-wood pile; 3-concrete; 4- other) 105. Drop structure comments (eg. downstream scour depth): 0

1 451 


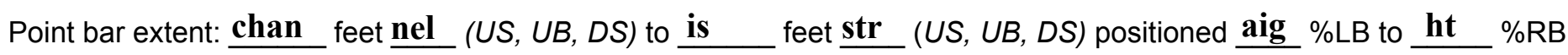
Material: fro

Point or side bar comments (Circle Point or Side; note additional bars, material variation, status, etc.):

$m$ the culvert exit. The channel is lined on the left bank side by a stone fill ridge which makes up the left bank in a sort of crude stone wall fashion. This ridge is about $5 \mathrm{ft}$ high and extends beyond $300 \mathrm{ft}$ DS. It is 5-6 ft high on the channel side and drops 4-5 ft down on the bankward side. On the right bank side, the bank appears to be stream material dug out and piled up. The gaps between the boulder protection is mainly silt, clay and sand

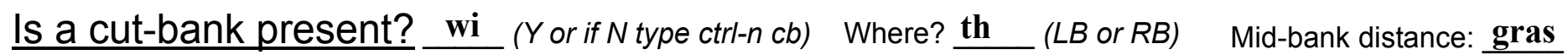

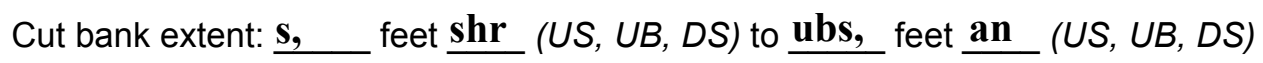

Bank damage: d (1- eroded and/or creep; 2- slip failure; 3- block failure)

Cut bank comments (eg. additional cut banks, protection condition, etc.):

brush growing in it. This protection is present from $0 \mathrm{ft}$ DS to $150 \mathrm{ft}$ DS. The bank material description by numbers above is reflecting the right bank material beyond $150 \mathrm{ft}$ DS on the right bank.

Is channel scour present? ( $Y$ or if $N$ type ctrl-n cs)

Mid-scour distance:

Scour dimensions: Length Width Depth:

Positioned $\%$ LB to $\underline{\mathbf{N}} \%$ RB

Scour comments (eg. additional scour areas, local scouring process, etc.):

-

NO DROP STRUCTURE

Are there major confluences? ( $Y$ or if $N$ type ctrl-n $m c)$

How many?

Confluence 1: Distance Enters on $\underline{\mathbf{N}}$ (LB or RB)

Type (1- perennial; 2- ephemeral)

Confluence 2: Distance Enters on (LB or $R B)$

Type (1-perennial; 2- ephemeral)

Confluence comments (eg. confluence name):

\section{F. Geomorphic Channel Assessment}

107. Stage of reach evolution -

1- Constructed

2- Stable

3- Aggraded

4- Degraded

5- Laterally unstable

6- Vertically and laterally unstable 
108. Evolution comments (Channel evolution not considering bridge effects; See HEC-20, Figure 1 for geomorphic descriptors):

-

$-$

NO POINT BARS

$\mathbf{N}$

$-$

$-$

$-$

$-$ 





APPENDIX F:

SCOUR COMPUTATIONS 
SCOUR COMPUTATIONS

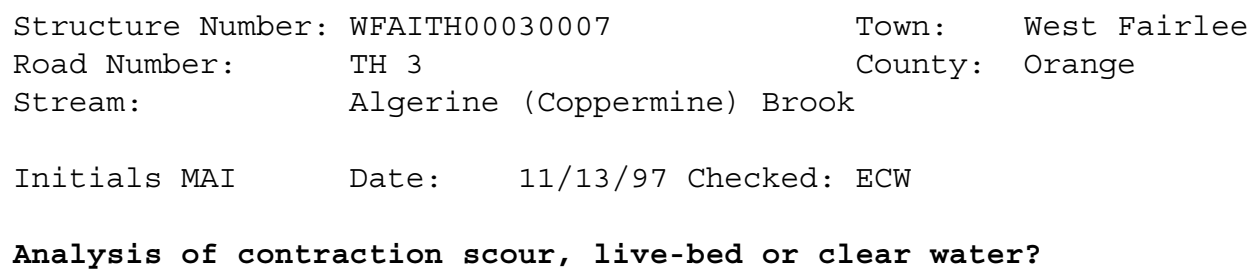

$0 \quad 0 \quad 0$

$\begin{array}{lll}0 & 0 & 0\end{array}$




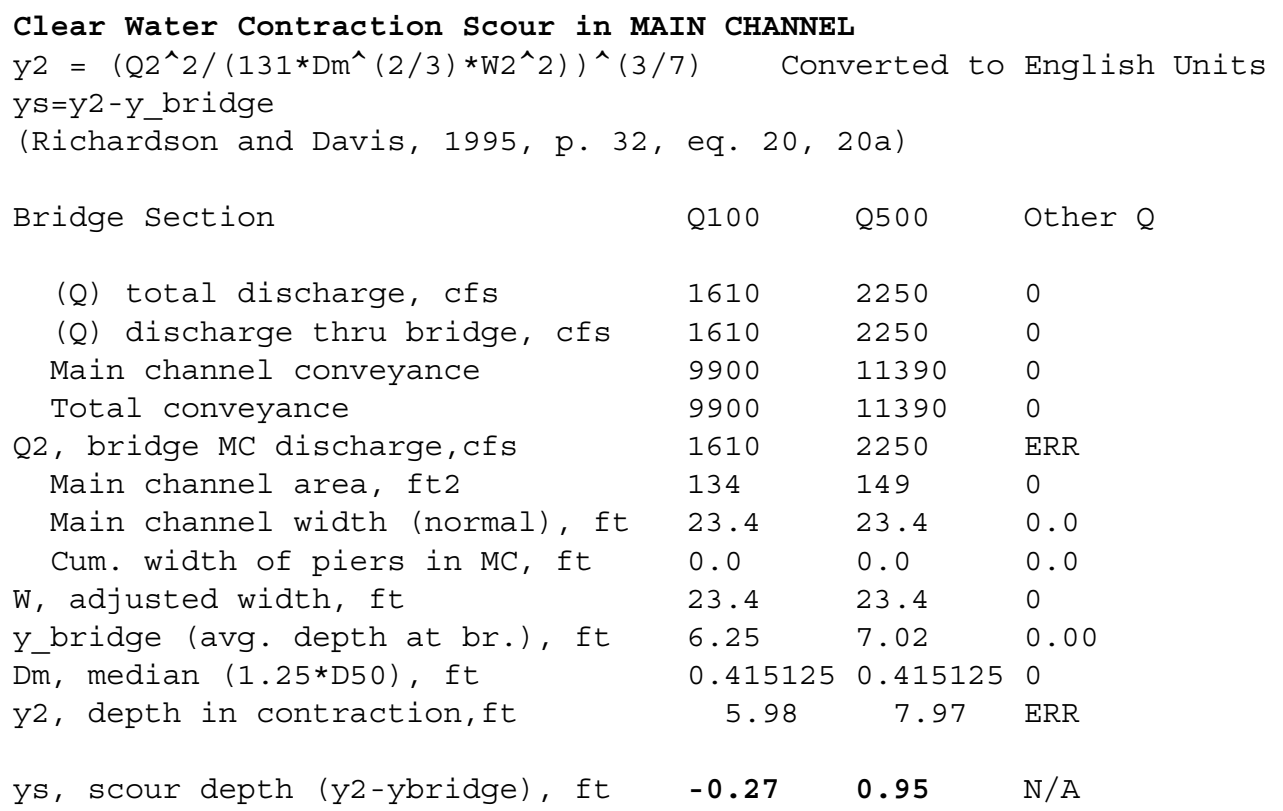

\section{Armoring}

$\mathrm{DC}=\left[\left(1.94 * \mathrm{~V}^{\wedge} 2\right) /(5.75 * \log (12.27 * \mathrm{Y} / \mathrm{D} 90))^{\wedge} 2\right] /[0.03 *(165-62.4)]$

Depth to Armoring $=3 *(1 / \mathrm{PC}-1)$

(Federal Highway Administration, 1993)

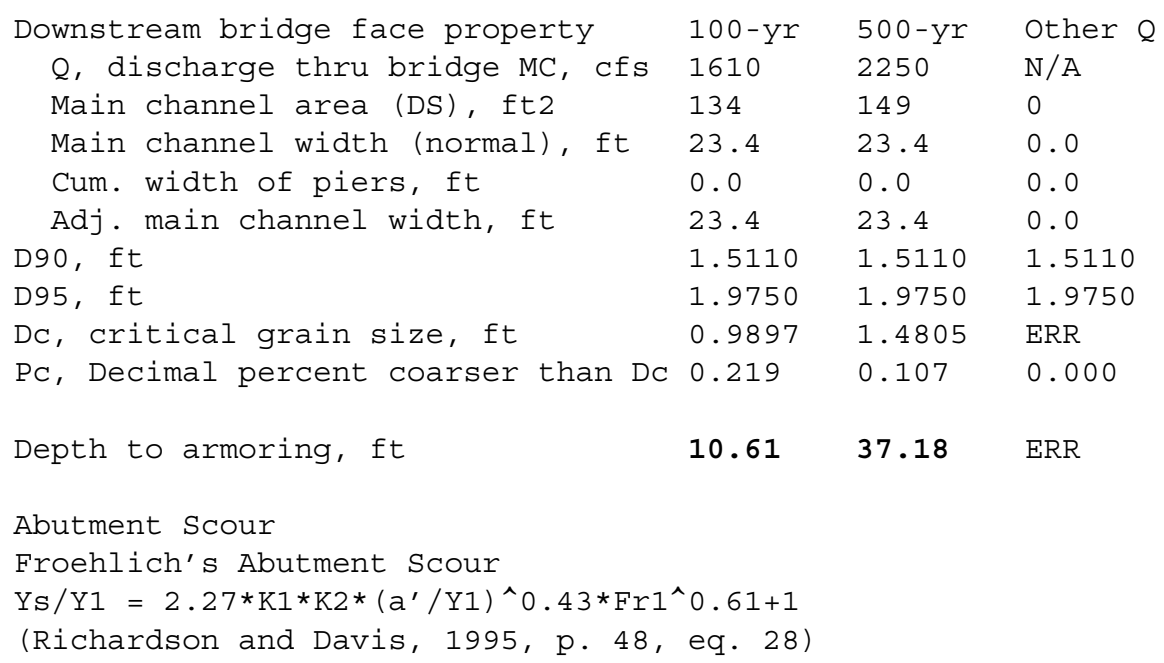




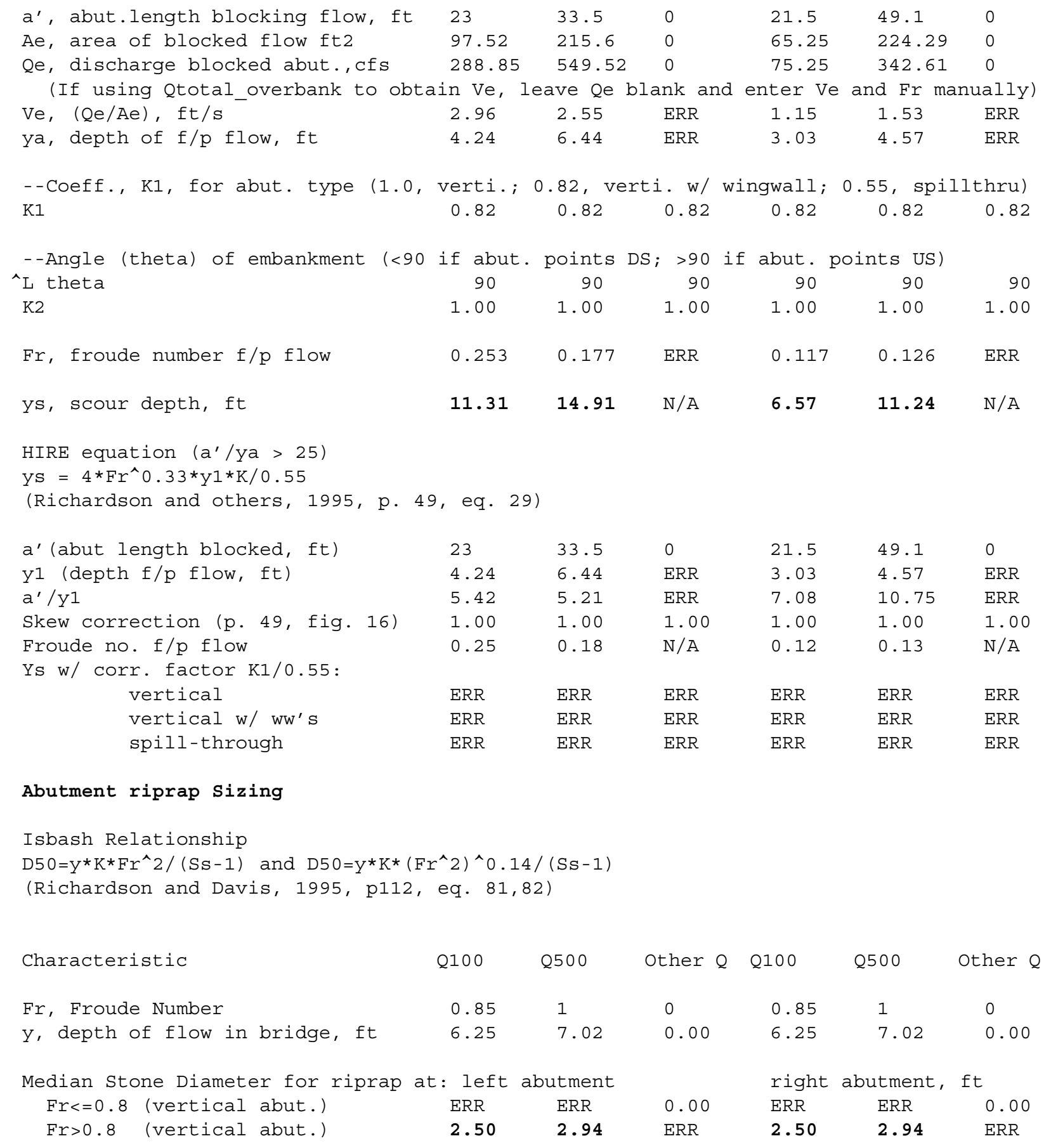


